\title{
GENEALOGIA DA CONSTITUINTE: DO AUTORITARISMO À DEMOCRATIZAÇÃO ${ }^{1}$ \\ Antônio Sérgio Rocha
}

Era possível a volta do Brasil à democracia sem os trabalhos da Assembleia Nacional Constituinte (ANC) de 1987-1988? Por que o formato adotado foi o de um Congresso Constituinte? Como entender o resultado de suas atividades?

Neste artigo, argumentamos que o regime instalado a partir de 1964 se proveu de atributos institucionais que efetivamente exigiram que a redemocratização se desse através de um processo constituinte. A reiterada constitucionalização das normas antidemocráticas e das medidas de exceção por parte dos militares e dos seus aliados civis, conjugada ao déficit de legitimidade da ordem autoritária, tornaram incontornável o recurso a uma assembleia constituinte para a instauração de uma institucionalidade democrática no país.

\footnotetext{
${ }^{1}$ Este texto é uma versão bastante compacta do material produzido pela pesquisa iniciada em 2008 no Cedec, sob amparo financeiro do CNPq, intitulada "Em busca do processo constituinte, 1985-88" e em curso de renovação. Os diversos depoimentos colhidos, a ampla documentação primária levantada e coligida e a literatura consultada são a base dos cinco volumes de Memória da constituinte atualmente em preparação pelo autor.
} 
O dédalo da transição política brasileira lançou raízes no híbrido institucional construído no autoritarismo. Não se pretende recontar aqui essa transição. $\mathrm{O}$ foco deste trabalho recai nas escolhas políticas feitas pelos protagonistas - tanto da oposição quanto do regime - a partir das instituições postas pela ordem autoritária. Busca-se evidenciar os momentos críticos dessa longa, complexa e sinuosa jornada rumo à transformação do regime, encadeando e integrando eventos, atores e contextos de decisão a partir de episódios ordinariamente tratados de forma separada: autoritarismo, transição política e Constituinte. O recurso à diacronia intenta destacar as linhas de continuidade e as inflexões dessa trajetória. Almeja-se com isso estabelecer as bases para a construção de uma narrativa que possa prestar-se à ulterior discussão de questões relativas à mudança política e construção institucional em termos de processos constituintes comparados.

\section{A configuração institucional do autoritarismo}

$\mathrm{Na}$ época, como ainda hoje, a caracterização institucional do período 1964-1985 constituiu-se em objeto de dissenso entre os analistas, pelos atributos heteróclitos que estavam presentes naquela configuração política. Indubitavelmente se tratava de um regime repressor e violador de direitos humanos, e desde logo calcado na Doutrina de Segurança Nacional. A ambígua moldura institucional que se estabeleceu a partir de sua instalação o fez receber denominações diversas: "situação autoritária” (Linz, 1973; Cardoso, 2006), "híbrido institucional” (Kinzo, 1988) e "regime burocrático-autoritário" (O’Donnell, 1990, Hagopian, 1996). Não é, entretanto, a discussão e a adequada classificação do período enquanto regime político que importam aos propósitos deste artigo, e sim pôr em evidência as restrições e os incentivos que as instituições representativas postas pelo autoritarismo exerceram sobre as escolhas políticas dos atores - em 
especial, suas consequências sobre a dinâmica da mudança da ordem constitucional instaurada pela coalizão civil-militar que empalmou o poder em 1964.

\section{Militarismo e instituições representativas}

A concepção tutelar das Forças Armadas (FFAA) sobre a política brasileira teve traços formativos muito ambivalentes. Ainda que se pusesse em xeque a possibilidade de democracia no país e se buscasse excluir outros atores do núcleo decisório, também se procurou salvaguardar a instituição militar e colocar em prática uma certa versão de governo representativo. Assim, desde o início, houve esforço para a montagem de uma concepção impessoal de governo. Ao tempo que desconfiavam e desprezavam os civis, as FFAA temiam que, ao assumir o controle do sistema político, sofressem um processo de autodesagregação. O temor maior era o surgimento de lideranças caudilhistas, com o potencial de antagonizar lideranças militares e esfacelar a organização - como era o exemplo visível das demais nações latino-americanas. Nesse sentido, os doutrinadores militares estabeleceram uma cuidadosa separação entre as funções de governante e as funções de membro das FFAA, por meio da criação de regras rígidas para evitar a politização entre os militares. São exemplos desse esforço (i) a ida obrigatória das lideranças carismáticas para a reforma; (ii) a manutenção da Presidência da República como cargo eletivo - ainda que pela via de um Colégio Eleitoral - e (iii) a manutenção dos limites tradicionais à duração do mandato, juntamente com uma norma contra a reeleição.

Ao se operar in tanden com esse aspecto, buscou-se a preservação de um sistema representativo. Se é verdade que os militares manipularam contínua e sistematicamente as condições nas quais as eleições ocorreram nos vinte anos do regime, também é fato que eles não tentaram eli- 
minar o sistema eleitoral ou substituí-lo por uma doutrina de representação inteiramente distinta - por exemplo, pelo corporativismo -, e ininterruptamente ocorreram eleições no país entre 1965 e 1982. Mesmo com um sistema partidário artificial e compulsoriamente criado (tanto em 1965 como em 1979), nunca se deixou de contar com uma agremiação oposicionista que atuasse abertamente no sistema político. Ao contrário dos demais regimes militares da América do Sul - ou do Estado Novo varguista -, o Congresso Nacional permaneceu aberto durante a maior parte do tempo, funcionando ao menos como locus de vocalização e resistência por parte da oposição parlamentar. Em termos institucionais, tratava-se de um regime político incompletamente autoritário.

\section{Aparato constitucional: a legalidade-sine-legitimidade}

Já em abril de 1964, poucos dias após o Golpe Militar, o 32 senador Aluísio de Carvalho Filho ${ }^{2}$ subia à tribuna do Legislativo federal para pedir publicamente a convocação de uma Assembleia Constituinte. A constitucionalização do novo regime, no entanto, só se daria dali a três anos: incorporando o arbítrio dos Atos Institucionais e das dezenas de Atos Complementares promulgados até então, a Carta Constitucional de 1967 criava um sistema político com vasta concentração de poderes no Executivo e no nível da União. De facto como de jure, ficavam abolidos os controles verticais e horizontais sobre os detentores do poder político. A Presidência da República se tornava o órgão máximo do regime. Buscava-se institucionalizar sua reprodução por meio de um Colégio Eleitoral, como se lia no artigo 76 da Carta: "O Presidente da República será eleito pelo sufrágio de um Colégio Eleitoral, em sessão pública e mediante votação

\footnotetext{
${ }^{2}$ Membro da UDN (BA) e suplente de Octavio Mangabeira. Depois se filiaria à Arena, vencendo a eleição para o Senado Federal em 1966.
} 
nominal"3. A escolha de governadores de estado, prefeitos de capitais e de municípios em área de segurança pública ficaria como atribuição exclusiva do chefe de Estado.

Do ângulo da sociedade, os direitos civis dos brasileiros eram virtualmente aniquilados. Conquanto tenha havido certa expansão de direitos sociais, sua regulação seguiria sob férrea tutela do Estado ${ }^{4}$. Mas no caso dos direitos políticos, houve ambiguidades (Carvalho, 2010). Muitas levas de cassações de mandatos e de incapacitação eleitoral eliminavam as lideranças que o regime considerava inaptas para o jogo político que praticava. Para o eleitorado em geral, entretanto, preservou-se o direito de voto em pleitos proporcionais (deputados federais, estaduais e vereadores) e para Senado Federal. E, embora dificultosa, não se vedava formalmente a criação de novas agremiações políticas.

Em 1969, a Emenda Constitucional n. 1 feita à Carta de 1967 extremaria a dimensão repressora do regime, constitucionalizando o liberticida Ato Institucional n. 5. No mesmo ano, a Lei de Segurança Nacional estabeleceria a pena capital para vários crimes de natureza política (Moreira Alves, 1984). A ambiguidade cessava. Entravam em latência as instituições representativas até então criadas. O regime se tornava abertamente ditatorial.

Mesmo profusa e minuciosamente escorada em constituições, atos e diplomas legais ${ }^{5}$, a coerção per se, entretanto, não

\footnotetext{
${ }^{3}$ Prescrevia-se a composição do Colégio Eleitoral através dos membros do Congresso Nacional e por três delegados indicados por cada Assembleia Legislativa estadual, adicionados de mais um delegado a cada 500 mil eleitores inscritos no estado, não podendo nenhum deles ter menos de quatro delegados. A eleição do Presidente se faria por maioria absoluta dos votos. Uma Lei Complementar regularia os procedimentos do órgão.

${ }^{4}$ Com a manutenção e mesmo incremento da concepção de "cidadania regulada" (Santos, 1979).

${ }^{5}$ Em depoimento à equipe do Cedec, Célio Borja opinou: "Esse vezo da linha-dura em ter Constituições, emendas, é algo ínsito à organização militar, por tratar-se de uma organização toda ela minuciosamente regulada. De modo que esse conjunto de atos e emendas dos militares de fato não tinha nada a ver com constitucionalização. Era na verdade um grande RDE, uma ampliação do Regulamento Disciplinar do Exército".
} 
se bastava como meio para consolidar o domínio político do "Movimento de Março". Era o seu futuro que colocava dúvidas: como estabilizar a nova ordem política - ao menos no indefinido período de preparação para um retorno à democracia prometido pelos militares ${ }^{6}$ ? Faltaria, talvez, o elemento que Célio Borja apontou mais tarde: "a questão é saber por que não veio da elite civil a doutrina autoritária que, acredito, teria sido a fórmula de estabilização do regime"7.

A hipótese do déficit de legitimidade seria elaborada de forma sistemática por Linz (1973), em seu clássico estudo sobre o caso brasileiro, ${ }^{8}$ resumida posteriormente em reportagem de periódico brasileiro:
No Brasil, a existência de uma situação autoritária [...]
é uma evidência das dificuldades que se apresentam para a institucionalização desse tipo de regime. [...]
As duas fórmulas de legitimação apartidária - a
carismática e a corporativa - não parecem estar

\footnotetext{
${ }^{6}$ As tentativas de dotar o regime de um arcabouço institucional ocorreram também de fora do governo. Em 1965, o jurista Goffredo Telles lançava a obra A democracia e o Brasil. Em 1966, o sociólogo Oliveiros Ferreira colaboraria intensamente no recolhimento de sugestões para a equipe de redatores da Constituição Federal de 1967, como relataria mais tarde, em 1986. Em 1972, o jurista Manoel Gonçalves Ferreira Filho apresentava, na primeira edição do seu livro A democracia possível, um projeto minucioso de institucionalização do regime. Considerava que "[...] a construção política que ora se impõe reclama a elaboração de uma nova Constituição. A de 1967, embora retocada em 1969, pela Emenda Constitucional n. 1, não atende às exigências da institucionalização revolucionária [...] nem é apta a assegurar a continuidade da obra da Revolução de Março. [...] Tanto assim é que a sobrevivência da Revolução tem sido garantida, segundo muitos pretendem, pelo Ato Institucional n. 5, que, na verdade, a suspende. [...] Essa é tarefa política magna: a democracia possível para o progresso na ordem" (Ferreira Filho, 1972, p.126).

${ }^{7}$ É possível que os ideólogos-juristas do regime tenham pressentido essa falta irreparável na montagem da nova ordem política, ao antecipadamente sustentarem que havia uma legitimidade intrínseca no movimento civil-militar de 1964, conforme se lê no prólogo do primeiro Ato Institucional: "A Revolução vitoriosa se investe no Poder Constituinte. [...]. Assim, a revolução vitoriosa, como Poder Constituinte, se legitima por si mesma”.

${ }^{8}$ Para uma crítica ao conceito de crise de legitimidade como explicação para a saída do autoritarismo e a transição política, ver Przeworski (1986).
} 
disponíveis para os governantes brasileiros. [...] No melhor dos casos, os governos se sucederão administrando a economia, mas adiando quase indefinidamente qualquer projeto sério e consistente de institucionalização política. Falando de forma pragmática, tal processo, combinando a administração, manipulação, decisões arbitrárias, campanhas aparentes e frequentes mudanças de pessoal, pode vir a ser bem-sucedido enquanto a economia for bem. Isso poderia assegurar a continuidade da situação atual, mesmo deixando para o futuro um vácuo político aterrador (Veja, 1973, pp.3-12).

Muito antes da crise econômica que, conforme vaticinava Linz, derruiria o regime, suas principais lideranças encetariam passos de afastamento do autoritarismo puro e duro. Uma nova dinâmica se instalaria no sistema político.

\section{0 híbrido se move}

Nem regime militar, nem ditadura, mas uma "democracia relativa" ${ }^{9}$. Tal era a avaliação que as lideranças das FFAA faziam da ordem política que instalaram no país. O próprio valor da democracia não era negado, e pretendiam que a repressão fosse uma medida excepcional, com duração temporária.

Tentativas de liberalizar o regime ocorreram desde o seu início. Castello assumiu a Presidência comprometendo-se com o retorno à democracia em dois anos; a linha-dura o obrigaria a adiar continuamente a promessa, ao final des-

\footnotetext{
9 "Eu discordo da denominação regime militar para o período de 1964 a 1985 no Brasil. Porque regime militar foi aquilo que eu vi no Peru, quando lá estive como representante da nação brasileira. Vi o presidente da República, general Velasco Alvarado, em reunião com seu ministério - todos eram da caserna, todos estavam fardados. Para mim, esse é que foi um regime militar. No caso do nosso país, vou pedir ajuda ao general Geisel para definir o que tivemos: o regime foi uma democracia relativa" (depoimento de Jarbas Passarinhos à equipe do Cedec, concedido em Brasília, em 2010).
} 
cumprida. Desde a sua posse, Costa e Silva anunciava a alvorada da democracia - mas presidiria o mergulho do país na ditadura escancarada pelo AI-5. Mesmo sob Médici, com o país convulsionado pela virulência repressiva, o ministro Leitão de Abreu tomaria a iniciativa de encomendar ao politólogo norte-americano Samuel Huntington um estudo para balizar a estratégia política do governo rumo a uma pretendida liberalização (Branco, 1982) ${ }^{10}$. Longe da imagem de grupo monolítico e do discurso da coesão interna, no interior das FFAA havia, na realidade, uma funda e continuada disputa entre as facções ditas linhas-dura e reformistas acerca dos rumos do regime.

No seio da oposição, existia igualmente uma vincada divisão acerca das visões e das estratégias da luta pela superação do autoritarismo. Um caso exemplar dessa disputa se deu em setembro de 1973, quando o cientista político Wanderley Guilherme dos Santos apresentou um trabalho 36 sobre a reorganização institucional do Brasil no plenário do Congresso Nacional. Ele sugeriu que a ordem política fosse descomprimida por etapas, buscando-se evitar os riscos de uma "recompressão", a ser desencadeada pelas forças extremistas (Santos, 1978). A tese de Santos gerou imediata reação na ala da oposição parlamentar composta pelos "autênticos" do MDB, que criticaram e combateram duramente a concepção gradualista da mudança de regime. Assim como a oposição clandestina, os "autênticos" pretendiam não menos que uma ruptura frontal com o regime. Também os oposicionistas se fraturaram em duas alas frequentemente irreconciliáveis.

Foi em 1974, com a posse do general Geisel na Presidência da República, que passos efetivos para a distensão do regime afinal ocorreram, ao serem introduzidas alterações

\footnotetext{
${ }^{10}$ Huntington formulará uma proposta de "mexicanização" do país, por meio da transformação da Arena em um partido dominante ao estilo do PRI. A proposta não terá acolhida pelo regime.
} 
no padrão de relacionamento regime-oposição. Da parte do governo, buscava-se uma gradual redução dos custos da coerção, ao tempo que operava para conter a crescente autonomia do aparato da repressão. Da parte da oposição, havia a exploração sistemática dos espaços políticos que surgiam a cada momento. A revitalização das instituições representativas do regime fez com que o MDB lograsse se organizar como uma poderosa força eleitoral, capaz de extrair importantes concessões junto às lideranças governamentais. Ainda assim, haveria um implacável fogo cruzado entre os extremistas do regime e da oposição, e a abertura política geiseliana se daria se forma lenta, gradual e segu$\mathrm{ra}^{11}$. Eppur se muove.

\section{Constituinte: o MDB e o projeto democrático}

A agenda política da oposição institucional se construiu em torno de quatro reivindicações fundamentais: retorno ao Estado de direito, anistia política, eleições diretas para presidente da República e uma nova Constituição. Esses pleitos e essas demandas delinearam o projeto democrático do MDB para o país (Kinzo, 1988). Por certo, a prioridade e a sequência de tais conquistas não eram, e não podiam ser, objeto de escolha deliberada - em parte, pela adversas circunstâncias políticas em que se vivia, mas também pelas disputas no interior da própria agremiação oposicionista.

O projeto democrático emedebista conheceria contornos efetivos em julho de 1971, quando, pela primeira vez, se lançou formalmente a proposta de convocação de

\footnotetext{
${ }^{11}$ A frase de Geisel foi dita em 29 de agosto de 1974, em reunião com dirigentes da Arena. Geisel destacava que promoveria o máximo de desenvolvimento econômico, social e político com o mínimo de segurança indispensável. Agregava que pressões para que esse processo fosse mais acelerado seriam um erro: "Tais pressões servirão, apenas, para provocar contrapressões de igual ou maior intensidade, invertendo-se o processo da lenta, gradativa e segura distensão" (Gaspari, 2003).
} 
uma Assembleia Nacional Constituinte, na chamada "Carta de Recife". Num ambiente nacional marcado pela euforia diante do "milagre" econômico, o partido oposicionista vivia uma fase de mutilações e cassações, numa quadra de persistentes reveses eleitorais. Da clandestinidade, muitos grupos contestavam a convivência da oposição legal com as regras autoritárias, e parte da agremiação passou a pregar a sua autodissolução como forma de protesto contra o regime. A Carta de Recife vinha para definir a Constituinte como uma necessidade e um objetivo concreto da luta do MDB contra o autoritarismo.

A tese da Constituinte, no entanto, operava mais para demarcar a divisão entre os emedebistas "autênticos" (que a defendiam) e os moderados (que a condenavam) do que para mobilizar o partido na atuação por uma nova ordem constitucional $^{12}$. Esse objetivo seria retomado e sistematizado nas movimentações do MDB visando às eleições 38 de 1974, com o lançamento da campanha "Constituinte com anistia”. Nenhum desses dois objetivos vingaria nesse pleito, contudo, o partido colheria uma expressiva e inesperada vitória eleitoral. Assim, detalhe importante, ao atuar no interior das regras estipuladas pelo próprio regime, o partido demarcava o que um analista denominará de "abertura pela via das eleições" (Lamounier, 1986). A reversão da sorte eleitoral alentaria o grupo dito moderado da oposição, robustecendo sua convicção da viabilidade da luta no seio da institucionalidade autoritária.

Tal como Castello em 1965, o governo Geisel não afrontou o resultado adverso das eleições. Mas reagiu com dureza, de modo a neutralizar a vantagem oposicionista e evitar novo avanço no pleito de 1978. O Pacote de Abril,

\footnotetext{
${ }^{12}$ Depoimento de Fernando Lyra ao autor, concedido em Recife, em julho de 2012.
} 
de 1977 , é a sua resposta ${ }^{13}$. O teor autoritário das medidas, o recesso forçado do Congresso e a cassação do líder do MDB, Alencar Furtado, levariam o partido a uma série de reuniões tensas em busca de uma forma de atuação e de resistência mais vigorosa do que as suas repetidas "notas de protesto”. Dessa crise interna do MDB surgiria a fixação da Constituinte como prioridade suprema para a oposição. Decide-se desencadear uma campanha de âmbito nacional pela convocação, como se ouviu no discurso feito por Ulysses Guimarães na ocasião:

Um povo só se autodetermina politicamente pela democracia [...]. O caminho histórico e universal indicado pela honestidade política e trilhado pelos democratas sinceros e coerentes é a convocação de uma Assembleia Nacional Constituinte, proposta urgente, institucional e salvadora do MDB (Delgado, 2006, p.188).

Doravante, o tema da Constituinte seria evocado e perseguido sistematicamente pelo MDB.

Em 1978, com a candidatura de Euler Bentes à Presidência da República pelo partido, haveria nova invocação por uma Constituinte. Ao encaminhar a votação no plenário do Colégio Eleitoral, discursava Ulysses:

Repito que o Movimento Democrático Brasileiro estrategicamente aceitou a via indireta com a esperança e o compromisso, se vitoriosos seus candidatos, de enxotálos da vida pública brasileira, com a imediata convocação

\footnotetext{
${ }^{13}$ A Emenda Constitucional n. 8 de 1977 modificou também a composição do Colégio Eleitoral: além de incorporar os senadores "biônicos" ao órgão, passava a adicionar um delegado para cada um milhão de habitantes de cada estado-membro, diminuindo ainda mais a representação daqueles estados com número elevado de eleitores por delegado, ao passo que aumentava um delegado a representação dos estados onde aquele número era baixo (Soares, 1984).
} 
de uma Assembleia Nacional Constituinte e a consequente eleição, pelo voto direito, universal e secreto do presidente da República, dos governadores de Estado, dos prefeitos municipais e dos senadores [...] (Delgado, 2006, p. 191).

Em 1979, logo em seguida à sanção da Lei n. 6.767 1979, recriando o pluripartidarismo no país, deputados e senadores lançaram o "Manifesto dos fundadores do PMDB”, em que se lia:

O PMDB prosseguirá e intensificará a luta travada pelo MDB em prol das grandes teses democráticas: manutenção do calendário eleitoral, eleições diretas em todos os níveis, defesa da autonomia dos municípios e fortalecimento da Federação, democratização do ensino, anistia ampla, geral e irrestrita, liberdade de informação, restauração dos poderes do Congresso e convocação de uma Assembleia Nacional Constituinte [...] (Delgado, 2006 p. 193).

A partir de então, o MDB passaria a promover atos, editar publicações e realizar seminários sobre a Constituinte, disseminando a discussão nos quadros partidários e em vários setores da sociedade. Em reunião no final de 1981, divulgava-se no boletim do partido:

As principais preocupações do partido voltam-se agora para 1982. Trata-se de utilizar o pleito direto para aprofundar a luta pela democracia e contra a política econômicofinanceira antinacional e antipopular, para conquistar grande vitória eleitoral e acelerar a convocação da Assembleia Nacional Constituinte (Delgado, 2006 p. 196).

Em preparação para a campanha eleitoral de 1982, o PMDB elaborou o documento "Esperança e mudança". Mais uma vez, lá se escrevia: "O MDB lutará por uma Assembleia 
Nacional Constituinte". Consumadas as eleições, e com as expressivas vitórias para governo de nove estados, a prioridade do partido se inclinou pelas alternativas para chegar à Presidência da República. A Constituinte teria então de esperar.

\section{Os juristas e a luta pelo Estado de Direito}

A campanha pela reconstitucionalização do país não se circunscreveu ao partido oposicionista. Papel fundamental também seria desempenhado pela Ordem dos Advogados do Brasil (OAB). O engajamento, entretanto, só se daria tardiamente, como lembrou um dos seus membros:

A OAB havia apoiado o Golpe em 1964, e, durante muitos anos, foi indiferente à política. Tanto que, em 1970, no auge do AI-5 e da repressão, não houve nenhuma manifestação pela abertura democrática no congresso da $\mathrm{OAB}$ aqui em São Paulo, cuja temática foi "A OAB e a ordem econômica" - como se a $\mathrm{OAB}$ não tivesse nada a ver com a ditadura militar que estava imperando no Brasil ${ }^{14}$.

O ano de 1977 marcaria uma inflexão nessa postura, com a eleição do jurista e historiador Raymundo Faoro para a presidência nacional da OAB. A partir daí, "toda a advocacia mais ligada ao projeto de abertura democrática filiou-se à corrente que Raymundo Faoro liderava na OAB, e a Ordem cindiu-se entre aqueles que se engajavam no processo de abertura e aqueles que não tinham esse engajamento" 15 .

Mesmo entre os advogados progressistas, haveria dissensões quanto à estratégia de retorno ao Estado de direito. Tão logo assume, Faoro se afasta de duas das principais bandeiras do projeto oposicionista: convocação de uma Assem-

\footnotetext{
${ }^{14}$ Flavio Bierrenbach, em depoimento concedido em 2010 à equipe do Cedec, em São Paulo.

${ }^{15}$ Flavio Bierrenbach, em depoimento concedido em 2010 à equipe do Cedec, em São Paulo.
} 
bleia Constituinte e promulgação de uma anistia política. $\mathrm{O}$ presidente da OAB prefere transferi-las para o elenco dos objetivos: "A Constituinte é um dos caminhos. Mas não é o único. [...] A anistia é um passo desta pacificação. Não é, talvez, um passo prévio" (Osiel, 1986).

Para o representante da $\mathrm{OAB}$, a reaquisição do habeas corpus e das garantias da magistratura eram as exigências mais prementes da luta política, como lembra Maria Victoria Benevides: "Faoro analisava que dar prioridade a um processo constituinte naquela hora seria abrir o caminho para todo tipo de disputa política, rompendo a frente contra a ditadura, contra o 'entulho autoritário' então vigente". E dizia: "Quem é que vai ser contra o habeas corpus, ou contra as garantias da magistratura, ou contra ampliar os direitos dos anistiados? Vamos nos concentrar nisso"16.

A implementação dessa estratégia levou Faoro a buscar negociações com o núcleo reformista do governo Geisel -

42 Golbery, Leitão de Abreu e, sobretudo, Petrônio Portella. E o fez com vigor. Em 1978, já sob a nova presidência, o Congresso Anual da Ordem foi realizado em Curitiba. O encontro ocorreu sob um clima de estranhamento generalizado. Faoro havia convidado Petrônio Portela, então o ministro da Justiça do regime, para participar da cerimônia inaugural. Setores da advocacia mais engajados com o projeto de abertura democrática reagiram com surpresa e desconcerto à iniciativa de Faoro, e a conferência do alto membro do governo gerou certa divisão na própria $\mathrm{OAB}$.

Enquanto o presidente nacional da $\mathrm{OAB}$ movia cuidadosamente suas peças no tabuleiro de xadrez das relações regime-oposição, outra vertente de juristas optou por uma manobra mais incisiva. Em 11 de agosto de 1977, o professor Goffredo Telles leu um manifesto na Faculdade de

\footnotetext{
${ }^{16}$ Depoimento da professora Maria Victoria Benevides à equipe do Cedec, concedido em São Paulo, em 2008.
} 
Direito da Universidade de São Paulo, no qual repudiava a ditadura militar e exigia a imediata restauração do Estado de direito. Sua "Carta aos brasileiros" era subscrita por dezenas de juristas e personalidades políticas e gerou um impacto profundo no país ${ }^{17}$ :

Denunciamos como ilegítimo todo Governo fundado na força. Legítimo somente o é o Governo que for órgão do Poder; Proclamamos a soberania da Constituição [...] e afirmamos que a fonte legítima da Constituição é o Povo; [...] o Poder Constituinte pertence ao povo, e ao Povo somente. Se uma ordem é legítima, por ser obra da Assembleia Constituinte do Povo, nenhuma outra ordem, provinda de outra autoridade, pode ser legítima. [...] a ordem que queremos é a ordem do Estado de Direito. A consciência jurídica do Brasil quer uma cousa só: o Estado de Direito já [grifos do autor] (apud Schubsky, 2007, p. 35).

Sob o influxo desses acontecimentos, em maio de 1980, com a presidência de Bernardo Cabral, acontecia o Congresso Anual da OAB em Manaus, em que se levantava explicitamente a bandeira da Constituinte. A partir dessa tomada de posição, a OAB convocaria uma reunião nacional específica - o Congresso Pontes de Miranda, realizado em Porto Alegre, em 1981 - no qual aprovaria um anteprojeto de sugestão para uma futura Constituição. Em 1983, em São Paulo, aconteceria o Congresso de Advogados Pró-Constituinte, com a produção de dois alentados anais, repletos de comentários e sugestões elaboradas para a futura ANC. Em 1985, a categoria exerceria influência e participaria decisivamente da futura Comissão Afonso Arinos e, em seguida, em assessoramentos na própria Constituinte, já em 1987-1988.

\footnotetext{
${ }^{17}$ Seu brado - "Estado de direito, já" - seria reaproveitado, em 1984, na pressão popular pelo restabelecimento da votação direta para presidente da República.
} 


\section{Do temor ao tremor - o abalo que vem da sociedade}

A contrapelo dos casos clássicos, a sustentação do autoritarismo brasileiro não se deu pela via do entrosamento sociedade-Estado (Cardoso, 2010). Aqui, fora nítida a opção do regime por desideologizar essa relação. Neste caráter desmobilizador do caso brasileiro, Linz (1973) destacaria a fragilidade e a precariedade do arranjo institucional instalado a partir de 1964.

Os eixos da crítica ao regime, vocalizadas pela Universidade, $\mathrm{SBPC}$, igreja católica e $\mathrm{OAB}$, centravam-se na denúncia e no combate às violações aos direitos humanos perpetradas pelo aparelho repressor, por meio do maciço e sistemático uso da violência, prisões e tortura contra os "subversivos". O terror de Estado se prestava a manter silente e obediente a sociedade.

Em fins da década de 1970, a irrupção das greves sindicais no ABC paulista marcaram a reversão do quadro. Ini-

44 cialmente uma luta dos trabalhadores contra o arrocho salarial, a contestação frontal à política econômica do regime acarretada pelas greves levou o movimento a uma escalada de enfrentamentos que, ao final, incluiu na pauta o fim da tutela do Estado nos conflitos trabalhistas - em outros termos, nada menos que o desmonte do próprio sindicalismo corporativista no país. O embate projetou novas lideranças e protagonistas; conjuntamente, sindicalistas e advogados trabalhistas se converteram em novos atores sociais, de marcante presença na cena pública.

A partir da greve na Scania, em maio de 1978, paralisações se espalharam por todo o país. A forte adesão às greves alcançou parte substancial das indústrias e daí se disseminou por segmentos diversos das classes médias médicos, professores, servidores públicos -, angariando simpatia e apoio de uma opinião pública outrora indiferente. Na década de 1980 , em aberto desafio ao marco regulatório do autoritarismo, o Brasil se tornou o país com 
o maior volume de greves no mundo, o que levou um analista a sustentar que, ao lado do gradativo acuamento do regime pelas vitórias eleitorais oposicionistas, uma "abertura por meio de greves" foi elemento decisivo na transição política (Noronha, 2009, p. 3).

Novos personagens entravam em cena. Com eles, uma vasta e heterogênea agenda de direitos se inscrevia no horizonte das mudanças políticas no país. Em 1979, a UNE foi reaberta e os estudantes readquiriram visibilidade e protagonismo. Em encontros regionais e nacionais, participantes do movimento sanitarista debateram os rumos da saúde pública no país; educadores formularam diagnósticos e reivindicaram mudanças no quadro educacional brasileiro; o incipiente movimento ecologista tomou corpo e firmou pauta de exigências para o meio-ambiente. Uma movimentação-cidadã teve encontro marcado com a futura Constituinte.

Ao veio político-institucional da transição se agregava, então, a vertente dos movimentos sociais. E parcela ponderável dessa vertente, mercê dos vínculos que estabeleceram entre si, com a igreja católica e com os sindicalistas, confluiu na constituição do Partido dos Trabalhadores (PT). O impacto dessa nova agremiação sobre a política nacional foi assim resumida: "A criação do PT em 1980 como um partido fortemente ligado aos sindicatos e aos movimentos sociais nascentes criou uma divisão de trabalho entre as oposições. Ao PMDB, coube a bandeira da democracia; ao PT, a da igualdade" (Noronha, 2009).

Não foram apenas as forças populares que organizaram suas reivindicações. A mobilização social também alcançou o empresariado. Cardoso (2005) assim pontuou a mudança:

O regime era até então sustentado pela burguesia, satisfeita e industrializando pelas benesses a que tinha acesso. A relação era tão próxima que, por muito tempo, Estado 
e burguesia pareciam ser a mesma coisa. Se, no entanto, desfrutava os benefícios, a burguesia não decidia. Com a liberalização do regime, os empresários percebem a brecha e se lançam ao controle da hegemonia, à busca de comandar as decisões da economia (Cardoso, 2005).

E começam a se dessolidarizar com o regime. Teve início a campanha pela "desestatização" da economia (Velasco e Cruz, 1995), que cada vez mais colocaria parte ponderável do empresariado numa postura de crítica às instituições econômicas do regime.

Os meios de comunicação desempenharam papel de peso no reconhecimento público dos atores sociais em constituição. A partir do abrandamento dos controles do regime, promovido por Golbery, de modo a acuar o aparelho repressivo, a própria mídia investiria na construção dos atores -, sejam aqueles ligados ao novo sindicalismo, sejam empresá46 rios considerados progressistas: Cláudio Bardela, Antônio Ermínio de Moraes, José Midlin. Em parte, essas novas lideranças empresariais aderiram às teses da oposição e elaboraram um discurso tomado ao MDB: distribuição de renda, ênfase no social, maior participação nas decisões econômicas.

Se os tremores advindos de uma sociedade em intensa movimentação escavaram um fosso na capacidade de controle do regime, abalo mais forte proviria do âmbito da economia. Em fins de 1982, o México declarou moratória de sua dívida externa, levando ao pânico o mercado financeiro internacional, período conhecido como "setembro negro". As fontes externas de financiamento da economia brasileira secaram subitamente, o que forçou os policy-makers do governo a manobras extremadas para evitar a insolvência do país. Na percepção pública, firmava-se a imagem de que somente sob uma democracia a política econômica readquiriria racionalidade e a indispensável defesa dos interesses nacionais. 
A crise econômica desmontava o último pilar da reivindicação de legitimidade clamada pelas figuras centrais do autoritarismo. Àquela altura do governo Figueiredo, a margem de manobra do regime reduzia-se agudamente.

\section{Aliança Democrática - remédio autoritário para o autoritarismo?}

Em 1982, a transição política brasileira conheceria seu decisivo ponto de inflexão. Naquele ano, as eleições diretas para governador de Estado, previstas para 1978 e posteriormente adiadas pelo regime, afinal se concretizaram. Como resultado, as oposições colheram expressiva vitória eleitoral. No sistema federativo, a conquista dos dez principais estados projetou os governadores de oposição como atores com visibilidade e recursos políticos de primeira ordem; cerca de metade dos brasileiros passou a ser governada por partidos oposicionistas, formando-se no país o que um analista denominaria "diarquia política" (Lamounier, 1986). Na Câmara dos Deputados, o avanço do PMDB levou à perda da maioria parlamentar pelo PDS, desarticulando a capacidade governativa do regime nessa arena. $\mathrm{O}$ impacto dessa perda para a entropia do regime não pode ser subestimado. Seria também aí, no Legislativo federal, que as oposições iriam buscar, de dentro das instituições do regime, obter sua superação: primeiramente, pela via disruptiva da emenda das diretas-já, e, no seu malogro, pelo uso do próprio Colégio Eleitoral - coração da reprodução da ordem autoritária.

Mas sigamos a cronologia. No dia 2 de março de 1983, o deputado Dante de Oliveira (PMDB-MT) apresentou a Proposta de Emenda Constitucional (PEC) n. 5, visando à extinção do Colégio Eleitoral e ao restabelecimento das eleições diretas para Presidência da República em 1984. A proposta apresentada pelo deputado da esquerda peemedebista alterava profundamente o rumo que a agremiação oposicionista vinha seguindo até então, cujo principal obje- 
tivo, como vimos, era o retorno do país à institucionalidade democrática através de uma Assembleia Nacional Constituinte (Leão, 2004). Poucos dias após a apresentação da PEC, o líder Freitas Nobre constituiria uma comissão de cinco deputados para elaborar um documento em defesa das diretas presidencias. Em 11 de março, o grupo encaminhou à executiva nacional um plano para a campanha nacional pelas diretas. Nascida no Congresso Nacional, organizada pelos políticos profissionais e apoiando-se prioritariamente nos partidos - em especial, no PMDB - somente depois é que as diretas para Presidência receberiam a adesão dos movimentos sociais e da população dos grandes centros, ainda mobilizada pelas greves de 1978 .

A partir daí, o movimento empolgaria o país; mesmo as hostes governistas não lhe seriam indiferentes. Deputados do PDS formaram o grupo pró-diretas na agremiação governista - e, posteriormente, contribuíram com 55 votos favoráveis na 48 votação da emenda. Ainda assim, e por pequena margem, a PEC das diretas-já foi, afinal, derrotada em 25 de abril de 1984.

O resultado da votação evidenciava, contudo, que mudara a relação de forças no Congresso, abrindo a possibilidade de que o governo deixasse de contar com maioria no Colégio Eleitoral. A percepção induziu as oposições a repensar sua estratégia, como aventava o senador Márcio Santilli (PMDB-SP) em plenário: "devemos formular uma ampla aliança, incluindo os deputados democratas do PDS, para que possamos cacifar uma transição [...]" (Diário do CN, 1984, p.2531).

No partido do governo, a conversão de um grupo de deputados pedessistas à tese das eleições diretas era apenas uma parte da crise que lavrava na legenda. A questão da escolha do candidato governista à sucessão presidencial desencadearia rivalidades e disputas inconciliáveis; seu acirramento levaria à crescente fragmentação do PDS, que culminou numa dissensão de próceres governistas que, na sequência, deixariam o partido e abandonariam o regime. 
A cizânia nas hostes do governo teve seu epicentro em junho de 1984, quando Sarney, na presidência do PDS, propôs publicamente a realização de prévias eleitorais para escolha do candidato governista. Combatidas pelos malufistas e desautorizadas pelo próprio presidente Figueiredo, a convenção partidária rejeitou as prévias em 11 de julho, desimpedindo o caminho para a candidatura de Paulo Maluf. Com o resultado, Sarney renunciou de imediato à presidência e também à sua filiação partidária, abrindo uma crise sem precedentes no PDS. Como recorda o senador Bornhausen,

A solução virá na madrugada do dia 10 para o dia 11 de junho de 1984. Foi acertado que Sarney renunciaria à presidência do PDS e eu a assumiria. Mas, na segunda reunião, eu também renunciaria, e essa seria a senha para a formação da Frente Liberal (Echeverria, 2011, p. 289).

Em 5 de julho, a dissidência rompeu com o PDS e formalizou a Frente Liberal. O ciclo se fechava. Civis levaram ao golpe de 1964. Civis encerrariam o regime que ajudaram a criar.

A convergência de trajetória entre a nova dissidência governista e a ala dos moderados de oposição não viria de imediato. No dia seguinte à derrota das diretas-já, partidos de oposição e o grupo pró-diretas do PDS empreendem articulações para que a mesa diretora do Congresso Nacional colocasse em votação emendas alternativas para as eleições diretas. Havia a PEC n. 35 de 1984, apresentada pelo governo dias antes da votação da Dantes de Oliveira, no calor da mobilização nacional, e que propunha diretas presidenciais para 1988. Com a mudança de cenário e ante a disposição dos oposicionistas de emendar a proposta e antecipar as eleições para 1985, o governo prestamente retirou sua PEC. Pelo lado da oposição, restava ainda a Emenda Theodoro Mendes ${ }^{18}$ e, no

\footnotetext{
${ }^{18}$ Apresentada em 02 de agosto de 1983, tratava-se da PEC n. 20 de 1983.
} 
começo de agosto, o líder Freitas Nobre pressionou a mesa do Congresso para colocar em pauta a sua votação. Esta e outras tentativas fracassariam. Como a conquista da Presidência da República pela via das eleições diretas estava inviabilizada para o PMDB, restava a alternativa do Colégio Eleitoral. Passo a passo, a direção nacional e a maioria do partido caminhariam para um acordo com os políticos da Frente Liberal.

A via da eleição indireta, no entanto, gerava intensa rejeição nas bases peemedebistas. No plenário, parlamentares se revezavam na denúncia da "farsa das eleições indiretas brasileiras", repudiando, conforme afirmara Luiz Henrique (PMDB-SC), "o pacto das elites, a costura por cima, o pacto pelo pacto, a conciliação pelo poder" (Diário do CN, 1984). Não era o que pensavam os moderados - ala do PMDB que as eleições de 1982 infundiram substancial incremento, graças aos efeitos das regras institucionais postas pelo regime. No pleito daquele ano, a lei eleitoral obrigava a vinculação do voto para todos 50 os cargos em disputa, vedando também as coligações em regime proporcional. O regramento inviabilizara o Partido Popular de Tancredo Neves e o levara a pedir reincorporação ao PMDB, de onde havia saído na criação do pluripartidarismo em 1979. Tendo feito escala no PP, ex-arenistas e conservadores estavam agora a bordo da nau oposicionista, inflando a ala dos moderados do partido ${ }^{19}$. No correr da campanha, há evidências de que essa facção já trabalhava com a possibilidade de derrota da Emenda Dante de Oliveira ${ }^{20}$. Como resumia

\footnotetext{
${ }^{19}$ Que internamente se organizarão no grupo Unidade. Instalado na $1^{\mathrm{a}}$. vice-presidência do novo partido, Tancredo demarcaria terreno: "O meu PMDB não é o PMDB do Dr. Arraes" (Couto, 1998, p. 431).

${ }^{20}$ Tancredo Neves foi a única ausência política importante da oposição no palanque do comício do dia 25 de janeiro de 1984, que reuniu cerca de 300 mil pessoas no centro da cidade de São Paulo. O governador mineiro dizia-se favorável às diretas, mas, na data do comício, preferiu receber o então presidente Figueiredo na exposição de gado em Uberaba (MG). Segundo Hagopian (1996), ali Tancredo deixava claro sua opção de criar espaço no regime para ser o fiador de uma transição negociada com as Forças Armadas, caso se confirmasse a derrota da emenda das diretas-já na Câmara, três meses mais tarde.
} 
em sua coluna o jornalista Castello Branco, o governador de Minas Gerais manobrava nos bastidores um novo movimento, articulado pelos moderados mas com apoio mais geral, que "[...] pode ser chamado de Tancredo-Já, ao invés de diretas-já" (Branco, 1984).

Os "históricos" do partido perderiam mais essa batalha. A ida ao Colégio Eleitoral se imporia à oposição. Em 23 de julho de 1984, o PMDB e outros partidos de oposição lançaram Tancredo Neves como candidato indireto à Presidência da República. A aliança com os dissidentes da Frente Liberal traria preciosos votos e incontáveis conexões no mundo interior do regime - urdidura a ser tecida, com os recortes aí colhidos, na vestimenta a ser usada no desfile final da ordem autoritária.

Na negociação entre frentistas e tancredistas, operaram mais uma vez as regras institucionais do regime. Na composição, Marco Maciel era o preferido da ala dos "autênticos" para ocupar a candidatura de vice-presidente na chapa do PMDB. A Emenda Constitucional n. 11 de 1978, no entanto, impunha perda de mandado ao candidato que disputasse eleições depois de trocar de legenda partidária. O veto atingia Maciel, mas não alcançava José Sarney, que havia sido eleito senador em 1978 - e era o preferido de Tancredo. Novamente, os membros históricos do partido rejeitaram a chapa com José Sarney na vice-presidência. Ulysses fecharia a questão: "Não dá, aritmeticamente falando, para elegermos Tancredo sem os votos da Frente Liberal, que, como contrapartida, ganhou o direito de indicar o vice e indicou. Ou vocês acham que devemos deixar o Maluf eleger-se?" (Echeverria, 2011, p. 284).

O dixit do ex-"Sr. Diretas" encerraria, afinal, a contestação interna ao ex-presidente do PDS e, em 7 de agosto, a Aliança Democrática de PMDB e Frente Liberal seria anunciada ao país. No dia 8, Sarney filiou-se à agremiação oposicionista. Três dias depois, a chapa seria aprovada na convenção peeme- 
debista. Consumava-se a opção do combate ao sistema "por dentro". A decisão, no entanto, parecia pesar no encontro. Discursou Tancredo: "Assumo, diante de nosso povo, o compromisso de promover, com a força política que a Presidência da República confere a seu ocupante, a convocação de poder constituinte para, com a urgência necessária, discutir e aprovar a nova Carta Constitucional” (Delgado, 2006, p. 289).

A intenção foi formalizada dias depois, quando se lançou o "Manifesto à Nação", assinado pelo PFL e pelo PMDB, que fixou as metas políticas para a nova ordem institucional:

É urgente a necessidade de proceder-se à reorganização institucional do país. Uma nova Constituição fará do Estado, das leis, dos Partidos políticos meios voltados para a realização do homem - sua dignidade, sua segurança e seu bem-estar. [...] Esse entendimento possibilita a Aliança Democrática estabelecer como compromissos impostergáveis e fundamentais com a Nação brasileira: restabelecimento imediato das eleições diretas, livres e com sufrágio universal, para Presidente da República, Prefeitos das Capitais dos Estados e dos Municípios considerados estâncias hidrominerais e dos declarados de interesse da segurança nacional. Representação política de Brasília; convocação de Constituinte, livre e soberana, em 1986, para elaboração de nova Constituição [...] (Delgado, 2006, p. 290).

No meio do caminho, porém, havia uma pedra: a disputa com Maluf no Colégio Eleitoral. E esse era um caminho repleto de armadilhas que os aliancistas teriam de desarmar. Como parte de sua estratégia para a eleição presidencial em 1985, o governo havia promulgado a Emenda Constitucional n. 22, aprovada em agosto de 1982. A nova regra estipulara que os delegados das assembleias estaduais não mais representariam o estado, e sim o partido majoritário na Assembleia Legislativa. Em outras palavras, os seis dele- 
gados que cada estado agregava à composição do Colégio Eleitoral passavam a ser escolhidos apenas pela agremiação política com o maior número de cadeiras na Assembleia Legislativa daquela unidade federada ${ }^{21}$.

Da parte do candidato aliancista, prosseguiam as negociações para a batalha contra Maluf e a montagem do futuro governo. Em público, Tancredo negava-se a comentar a convocação de uma Constituinte, embora se soubesse que ele discretamente recolhia propostas e sugestões técnicas de como fazê-la ${ }^{22}$.

Em 8 de janeiro de 1985, a poucos dias da reunião do Colégio Eleitoral, Ulysses Guimarães entregaria ao candidato Tancredo Neves o plano de governo da Aliança Democrática, intitulado "Nova República"23. Nele, estavam previstas eleições diretas nas capitais em 1985 e eleições para uma Assembleia Nacional Constituinte em $1986^{24}$. No discurso em que lançou a Nova República, proclamaria Tancredo: "Ela será iluminada pelo futuro Poder Constituinte, que, eleito em 1986, substituirá as malogradas instituições atuais por uma Constituição que situe o Brasil em seu tempo”. (Delgado, 2006, p. 293)

\section{Nova República - o cálculo da constituinte}

No início de 1985, às vésperas da posse do novo governo, o Congresso Nacional instalou uma Comissão Interpartidária

\footnotetext{
${ }^{21}$ No Rio de Janeiro, do total de seus 5,5 milhões de eleitores, apenas aquele 1,5 milhão que votou no PDT ganhou representação no Colégio Eleitoral. No Rio Grande do Sul, seriam representados somente os 1,25 milhão de eleitores que votou no PDS; os demais 2,5 milhões, não.

${ }^{22}$ Sabia-se que Tancredo havia incumbido o jurista Clóvis Ramalhete de elaborar um esboço da convocação da Assembleia Constituinte, assim como de um projeto de Constituição (Salgado, 2007, p.114). Ramalhete havia sido Consultor-Geral da República no governo Figueiredo. Antes, elaborara parecer favorável à extensão unilateral do mar territorial brasileiro para 200 milhas marítimas. Colaborou também no projeto da Lei de Anistia, em 1979.

${ }^{23}$ Expressão criada pelo publicitário Mauro Salles conforme depoimento de Fernando Lyra ao autor, concedido em Recife, em 2012.

${ }^{24}$ Note-se que o programa político do PDS também contemplava a convocação de uma Constituinte.
} 
sobre Legislação Eleitoral e Partidária. O objetivo era dar os primeiros passos rumo à nova institucionalidade democrática, por meio da eliminação de alguns dos principais entraves legais postos na ordem pública pelo autoritarismo. Tratava-se do que à época se chamou "remoção do entulho autoritário". A empreitada era operada também no âmbito do Ministério da Justiça, sob o comando de Fernando Lyra, antigo militante da ala dos emedebistas "autênticos" convertido em liderança tancredista. De imediato, se pretendia despojar o híbrido institucional do ancien régime daqueles dispositivos que tolhessem a definição dos parâmetros a presidir a convocatória da longamente almejada Assembleia Nacional Constituinte - quando, afinal, se restabeleceria a ordem democrática em sua plenitude.

A definição e a escolha de tais parâmetros se arrastariam por cerca de dois anos, consumidos pelo fragor dos debates e das manobras pelas distintas alternativas institu54 cionais para a nova ordem: Constituinte derivada ou originária? Exclusiva ou congressual? Provida de anteprojeto ou não? No mais das vezes, as disjuntivas implicavam polarização entre as forças políticas. Personagens das correntes progressistas e conservadoras multiplicavam seus argumentos, escritos e pressões em incontáveis reuniões, mesas-redondas e conferências nas universidades, nos jornais, nas televisões, em centros de pesquisa (como no próprio Cedec), nas comunidades de base e nos partidos políticos, numa campanha aberta e incisiva para obter a prevalência de suas visões e de seus interesses ${ }^{25}$. O país vivia uma situação constituinte.

No plano institucional, entretanto, os membros da cúpula da Aliança Democrática operavam para manter sob controle o processo de construção constitucional. A emen-

\footnotetext{
${ }^{25}$ Por limitação de espaço, não indicamos aqui esse rico elenco de publicações que se saiba, pendente até hoje de organização e análise.
} 
da convocatória da ANC, instituindo um Congresso Constituinte em bases derivadas da Constituição federal de 1967, foi agenciada pelo ramo pefelista do consórcio político. Do lado do PMDB, Ulysses Guimarães interviria decisivamente para abortar a proposta de plebiscito sobre a questão, tal como previsto no substitutivo elaborado por um relator defenestrado pessoalmente pelo grande timoneiro da transição. Por fim, o próprio presidente Sarney tentaria legar ao esquecimento das gavetas do Ministério da Justiça o meticuloso e progressista Anteprojeto Constitucional da Comissão Arinos. A Nova República parecia "um imenso pastiche da transição" (O’Donnell, 1987); pessimismo e apreensão quanto aos trabalhos da futura Constituinte rondavam as forças progressistas. No que se segue, apontaremos os principais aspectos preliminares da ANC.

\section{A Reforma Política do PMDB}

Com relatoria do deputado João Gilberto Lucas Coelho (PMDB-RS), a Comissão Interpartidária apresentou a proposta que resultou na Emenda Constitucional n. 25 $5^{26}$. Modificações profundas eram introduzidas no sistema político do país. Ficava liberada a criação de novas agremiações, inclusive aquelas anteriormente ilegais; concedia-se o direito de voto aos analfabetos; punha-se fim ao instituto da fidelidade partidária, permitindo aos políticos a livre-troca de agremiação; ficava abolida a sublegenda; revogava-se o artigo que previa a adoção do sistema distrital misto; suprimia-se o voto vinculado; eliminava-se as restrições da Lei Falcão à propaganda eleitoral; coligações para eleições proporcionais voltavam a ser permitidas; eram suspensas as cassações políticas e sindicais; concedia-se representação política ao Distrito Federal, de modo que Brasília passaria a eleger três senadores e oito deputados federais; por fim, introduzia-se

\footnotetext{
${ }^{26}$ Promulgada em 15 de maio de 1985.
} 
a eleição direta para presidente da República e vice-presidente, em dois turnos ${ }^{27}$.

Nesse mesmo período, Coelho - parlamentar oriundo da ala dos emedebistas "autênticos" - também ficaria responsável pela relatoria de dois outros projetos de lei. Num deles, introduzia alterações na Lei Orgânica dos Partidos Políticos, as quais concediam às agremiações a possibilidade de registro na Justiça Eleitoral, prescindindo da publicação de estatuto previamente aprovado em convenção nacional, bastaria apenas que se provasse o funcionamento de diretórios regionais, convenções e executivas nacionais ${ }^{28}$. Completando a reforma política sob patrocínio peemedebista, Coelho relataria também o projeto que alterava o Código Eleitoral e determinava o restabelecimento, em novembro de 1985, das eleições nas capitais dos estados, dos municípios considerados área de segurança nacional e das estâncias hidrominerais, suspensas desde 1968.

Os direitos políticos dos brasileiros estavam plenamente restabelecidos. Parte do projeto democrático do antigo MDB se materializava, derrogando em ampla medida as instituições representativas criadas pelo autoritarismo. Uma ordem poliárquica despontava no país.

\section{Exclusiva ou congressual? A batalha da convocatória}

Ao correr da transição política, argumentos os mais variados foram esgrimidos por vozes ligadas ao regime para combater a convocação de uma Assembleia Constituinte. Para esses juristas, um alegado poder reformador do Congresso Nacional (à exceção da República e da Federação) seria o instrumento adequado para depurar, da ordem pública em

\footnotetext{
${ }^{27}$ As eleições eram marcadas para 15 de novembro de 1990, já que o mandato presidencial continuava a ser de seis anos, tal como definido na EC n. 1 de 1969.

${ }_{28}$ Note-se que a lei partidária de 1979 não é alterada. A legislação infraconstitucional para formar partidos continuou em vigor e só mudaria em 1995, com a promulgação de uma nova lei partidária.
} 
vigor, os excessos autoritários introduzidos pela Emenda Constitucional n.1 de 1969. Nessa ótica, a reconstitucionalização do país demandada pela oposição poderia ser alcançada por meio do retorno puro e simples à moldura da Constituição de 1967.

A tese recebeu dura e frontal contestação em livro que Raymundo Faoro publicou em 1981. Para o ex-presidente da $\mathrm{OAB}$, nenhum remendo constitucional à guisa de reforma contemplava o que realmente estava em jogo no país: a recuperação da legitimidade da ordem política. O livro e a cerrada argumentação de Faoro exerceriam considerável impacto no debate nacional. Uma versão menos intransigente da reconstitucionalização passaria a tomar corpo entre os partidários do regime. Tratava-se da alternativa de criação da nova ordem institucional por meio de um Congresso Constituinte. Na defesa do modelo, postava-se um celebrado constitucionalista, conspirador de primeira hora do movimento de 1964.

Em agosto de 1981, discursando na tribuna do Senado Federal, Afonso de Arinos de Melo Franco proclamava que "a situação do Brasil [...] só se resolverá por meio de uma Assembleia Constituinte Instituída”, a ser promovida pelo Legislativo, que traria "uma solução jurídica, quanto à sua essência, mas política, quanto à sua forma”. E propunha, no fim, "a outorga de poderes constituintes ao futuro Congresso Nacional, a ser eleito em 15 de novembro de 1982”, já que a concessão desses poderes constituintes seria "a melhor solução, e mesmo a única, em termos jurídicos, para o restabelecimento indispensável da ordem constitucional" (Franco, 1982 p. 11).

No ano seguinte, a Casa de Rui Barbosa (RJ) abrigou um ciclo de conferências acerca da Constituinte, sob o título geral de "Reforma Constitucional". Num dos encontros, o jurista Célio Borja também faria a defesa da Constituinte Instituída, a ser instalada no Congresso Nacional. Meses 
mais tarde, já como assessor do presidente Sarney, Borja redigiria a emenda convocatória da ANC calcada em idêntica base doutrinária. Sigamos o argumento.
Havendo Governo, "reforma-se" a ordem normativa existente. Mas como a reforma constitucional tem o mesmo efeito jurídico do ato constituinte - uma vez que repele a invocação do direito adquirido sob a lei velha - é, muitas vezes, tida pelo Direito e seus cultores como da mesma natureza do poder de constituir os fundamentos da lei e do Governo. [...] Daí resulta que, enquanto não dissolvido o Governo, isto é, as instituições governativas, não caberia criar outro órgão que possa ostentar o atributo de depositário do poder constituinte originário, pois ter-se-ia por dissolvido ou inexistente o Governo emanado da ordem constitucional preexistente; ou, em defesa desta, estariam os governantes autorizados a resistir a essa verdadeira revolução (Machado e Torres Jr., 1997 p. 23).

Em 28 de junho de 1985, o presidente Sarney encaminhava seu projeto de convocação da Assembleia Nacional Constituinte. A forma escolhida foi a de uma emenda à Constituição em vigor, que receberia críticas por ligar a construção de uma nova ordem às regras do status quo constitucional. A Constituinte era declarada livre e soberana, sem qualquer restrição (mesmo a de rever a república e a federação), composta por senadores e deputados federais, e funcionando paralelamente às atividades normais do Congresso. A eleição dos constituintes coincidiria com o pleito de 1986 para governador, senador e deputado federal.

No início de agosto, formou-se uma comissão mista para analisar a PEC da convocatória. Por quatro meses, no Congresso e em diversos outros fóruns que aconteciam no país, o relator da PEC, Flavio Bierrenbach (PMDB-SP), participaria de longos debates sobre o caráter da Consti- 
tuinte, a forma de eleição, plebiscito, proporcionalidade na representação, funcionamento do Congresso, a questão dos senadores eleitos em 1982 e outros tópicos. À medida que os trabalhos avançavam, evidenciava-se a tensão no governo, no Congresso Nacional, em setores militares e na sociedade sobre a fórmula adotada para a futura Constituinte. Por fim, no dia 15 de outubro, o relator surpreendia com um relatório contendo alternativas inovadoras, em que propunha um plebiscito para que os brasileiros escolhessem uma Constituinte congressual ou exclusiva; a separação das eleições para constituinte e para governador de Estado; o aprofundamento da "remoção do entulho autoritário" da ordem constitucional em vigor, para efetivamente permitir uma Constituinte livre e soberana ${ }^{29}$; a ampliação da anistia para civis e militares afastados no regime militar; o funcionamento de uma comissão legislativa congressual enquanto estivesse sendo elaborada a Constituição; a coleta de sugestões à ANC por meio das Câmaras Municipais.

No momento de apresentação de seu parecer, o relator abriu diante da comissão mista uma mala contendo 70 mil telegramas e cartas recebidas de todo o país. Eram as manifestações em favor de uma Constituinte exclusiva. A reação do governo e a alta cúpula do PMDB foi dura e imediata, e um Substitutivo alternativo foi preparado para derrubar o parecer do relator. Oficialmente, a autoria era do deputado Valmor Giavarina e seu texto estipulava a convocação de um Congresso Constituinte. A destituição de Bierrenbach da relatoria da PEC se dava no último dia de trabalho da comissão, no momento que o parlamentar se preparava para ler seu Substitutivo, como ele evoca:

\footnotetext{
${ }^{29}$ Deveriam ser excluídos da Constituição Federal de 1967/emenda Constitucional n. 1 de 1969 o estado de emergência, as medidas de emergência e o art. 181, que versava sobre a aprovação e a exclusão de apreciação judicial dos atos da "Revolução" desde 1964.
} 
Tive uma conversa com o Dr. Ulysses dois ou três dias antes da votação do meu Relatório. Eu não sabia que iria ser destituído; essa foi uma solução que, acredito, tenha sido decidida na véspera. Dr. Ulysses me disse que meu Substitutivo não ia passar, e que era consensual e majoritária a fórmula original vinda do Palácio do Planalto, elaborada por Célio Borja. Essa fórmula foi forjada pela ala-PFL da Aliança Democrática; acredito que tenha sido feita pela mão do Marco Maciel. O episódio da minha destituição ocorreu no Plenário da Comissão Mista. Alguém lá propôs que substituíssem o relator e que nomeassem um relator substituto, e o deputado Valmor Giavarina já estava com tudo pronto. Giavarina apresentou o substitutivo dele de última hora ${ }^{30}$. O comentário que eu fiz a respeito do seu substitutivo foi de que era "medíocre na forma e covarde no conteúdo". Nunca tive vontade nem coragem de lhe perguntar se foi ele mesmo que fez. Foi só isso que eu disse ali. Me retirei da Comissão e fui embora. Nunca perguntei a ninguém os motivos, nunca passei recibo da minha destituição ${ }^{31}$.

A Constituinte brasileira seria congressual, como desejavam o governo e o PMDB ulyssista.

\section{O notável anteprojeto dos "Notáveis"}

Atribui-se a Tancredo Neves a ideia de criar uma comissão para elaborar um anteprojeto de Constituição. Dizia que seu papel era ser o "sal da terra", de modo a provocar o

\footnotetext{
${ }^{30}$ Isso ocorreu em 13 de outubro de 1985 . Giavarina era deputado federal pelo Paraná e antigo militante da ala dos "autênticos" do MDB. Tinha sido vice-líder do PMDB na Câmara Federal e cabeça de fila do grupo Só Diretas. Em setembro de 1984, discursara no Congresso Nacional sobre as alternativas de convocação de uma ANC. Também havia escrito um opúsculo sobre a Constituinte que lhe valera um bilhete elogioso de Tancredo Neves.

${ }^{31}$ Depoimento concedido à equipe do Cedec, em São Paulo, em 2010.
} 
debate nacional e despertar a participação da cidadania ${ }^{32}$. Sarney levaria adiante o projeto de Tancredo, instituindo em 18 de julho de 1985 a Comissão Provisória de Estudos Constitucionais. No país, várias das experiências constituintes anteriores contaram com a preparação de anteprojetos. Mas, no clima político da Nova República, a elaboração de um anteprojeto constitucional se converteria em outro ponto de discórdias entre as diversas forças políticas.

Desde o início, a chamada Comissão Arinos foi malvista por consideráveis posições e correntes. Havia o temor de que o resultado de seu estudo confluísse num "Projeto de Constituição do governo", a ser encaminhado à ANC como forma de pressão dos poderes constituídos. Desde logo batizada de "Comissões de Notáveis", foi tema de muitos debates e discursos na campanha eleitoral. Havia uma quase unanimidade de críticas $^{33}$. Ademais, sua composição majoritariamente conservadora deixava entrever a produção de um documento pouco afinado com o que desejavam as forças progressistas no país ${ }^{34}$.

\footnotetext{
${ }^{32}$ Em seu discurso no final da ANC, Arinos lembraria: "Em 1985, já eleito pelo Colégio Eleitoral, o presidente Tancredo visitou o presente orador, no Rio, e o convidou para presidir uma comissão incumbida de redigir o anteprojeto da Constituição" (Salgado, 2007).

${ }^{33}$ A entrevista de Arinos (Veja, 1986) em nada contribuiria para dissipar a imagem de comissão de "notáveis", alheios ao sentimento geral: "A OAB tem muitas restrições à Comissão Arinos e à ideia de anteprojeto. Como é fazer um anteprojeto de Constituição praticamente brigado com a $O A B$ ? $O$ senhor tem qualquer contato com a entidade ou com seu presidente, Hermann Baeta? Não conheço o Hermann Baeta e não dou nenhuma importância ao que ele diz. Ele é presidente de uma instituição de classe, e não tem uma situação relevante no meio jurídico. Não é um líder da ciência jurídica do país. Por causa desse tipo de afirmação, o senhor muitas vezes é acusado de elitista. Sou elitista. Sou professor de Direito, e ele não. Fiz concurso. Essa falta de intercâmbio com a OAB causa prejuizo à Comissão? Somos uma emanação do governo federal. Nós não procuramos ninguém. [...] Quero ver se a VEJA vai fazer uma entrevista nas Páginas Amarelas com o Hermann Baeta.".

${ }^{34}$ Logo no início dos trabalhos da Comissão, a imprensa pretendeu identificar dois grupos em confronto: no campo majoritário, considerado "conservador", havia "ideólogos de direita" (em que pontificavam Ney Prado, Miguel Reale e Gilberto Ulhôa Canto) e empresários (como Sergio Quintella e Luís Eulálio Bueno Vidigal); o campo "progressista" era composto por juristas, professores e jornalistas, como José Afonso da Silva, Barbosa Lima Sobrinho, Cândido Mendes, Evaristo de Moraes Filho e Joaquim de Arruda Falcão.
} 
Nesse ponto, como em alguns outros, a Comissão Arinos foi uma espécie de laboratório do que aconteceria posteriormente na própria Constituinte: uma intensa controvérsia ideológica entre os membros atravessou o andamento dos seus trabalhos. Ao final, um documento surpreendentemente progressista e inovador indicava qual das tendências havia triunfado na Comissão.

Para Cittadino (2000), foram duas as principais razões para a reversão das expectativas negativas. Inicialmente, por não ter se concretizado o temido pacto entre os ideólogos de direita e os empresários. De outra parte, por não ter havido da parte dos "conservadores" o grau de comprometimento e a assiduidade aos trabalhos dos comitês temáti$\cos ^{35}$ que os representantes do grupo "progressista" tiveram, como assinalado por Ney Prado na Folha de S. Paulo na edição 19 de setembro de 1986 :

Os chamados conservadores são homens com múltiplas atividades e não podiam comparecer com assiduidade. Os progressistas, mais determinados, começaram a frequentar mais as reuniões. E ficou tão marcante a divisão que alguns conservadores até desistiram. Eles diziam: "O que adianta ir, se os nossos pontos de vista estão sendo triturados?”.

Impondo-se nas atividades da Comissão Arinos, desde o início o campo progressista imprimiu aos trabalhos uma diretriz orientada pela chamada doutrina constitucional comunitarista, a partir do Anteprojeto de Constituição ela-

\footnotetext{
${ }^{35}$ A Comissão Arinos era integrada por dez comitês temáticos distintos, tendo cada um deles um coordenador, um secretário e um relator. Os comitês temáticos eram os seguintes: 1) Princípios Fundamentais da Ordem Constitucional, Organização Internacional e Declaração de Direitos; 2) Federação e Organização Tributária; 3) Poder Legislativo e Organização Partidária; 4) Poder Executivo; 5) Poder Judiciário e Ministério Público; 6) Educação, Cultura e Comunicações; 7) Condições Ambientais, Saúde, Ciência e Tecnologia; 8) Ordem Econômica; 9) Ordem Social; 10) Defesa do Estado, da Sociedade Civil e das Instituições Democráticas.
} 
borado por José Afonso da Silva (Cittadino, 2000). A influência desse escrito seria marcante. Segundo a autora, uma nítida linha de continuidade doutrinária (e mesmo de passagens literais) percorre o anteprojeto feito por Silva, o documento promulgado pela Comissão Arinos e o texto final da Constituição Federal de 1988. Baseado em artigos das Constituições portuguesa e espanhola - que, por sua vez, haurem inspiração no dito "novo constitucionalismo alemão" do pós-guerra -, o Anteprojeto José Afonso da Silva apresentava um completo e exaustivo sistema de direitos e garantias individuais e coletivas ${ }^{36}$. O decisivo, entretanto, era a criação de mecanismos processuais para materializar e tornar eficaz o rol de direitos humanos que se propunha. $\mathrm{O}$ temor de que a nova Constituição viesse a padecer, como as anteriores, de uma espécie de inoperância crônica, o levava a propor novos institutos processuais, consagrando o dever de prestação por parte do Estado ${ }^{37}$.

O Anteprojeto Silva propunha também a criação de um Tribunal Constitucional. Com a função essencial de "guardião da Constituição", seus pronunciamentos a propósito da constitucionalidade das leis obrigariam não apenas todos os órgãos do Poder Judiciário como os demais poderes do Estado.

Mas não apenas da contribuição do anteprojeto Silva viveu a Comissão Arinos. Outros juristas e militantes dos direitos humanos, como o professor Candido Mendes, aportaram importantes contribuições ao relatório final. Além disso, milhares de sugestões de entidades e de cidadãos lhes foram encaminhadas. Audiências com debates públicos e

\footnotetext{
${ }^{36}$ Estavam previstos, dentre outros, o direito à cultura, ao meio ambiente, à associação sindical, à proteção jurídica, à informação, à escusa de consciência, ao lazer, à integridade moral e imagem, de acesso aos registros de informações, de greve etc.

${ }^{37}$ Mais tarde, no texto final da Constituição de 1988, esses institutos se tornariam o "mandado de injunção", que obrigava o Congresso Nacional a legislar para suprir a norma faltante, e a "ação de inconstitucionalidade por omissão".
} 
longas jornadas de trabalho marcaram a atuação da Comissão, que concluiria sua tarefa somente em 18 de setembro de 1986 - quatorze meses após o decreto que a instituíra.

O presidente José Sarney não contava que a proposta tivesse feições tão inovadoras e progressistas - e, sobretudo, que recomendasse o sistema parlamentarista. Sarney decidiu por não enviar o Anteprojeto da Comissão à Assembleia Nacional Constituinte, remetendo-o por despacho presidencial em 24 de setembro, ao Ministério da Justiça, onde foi arquivado. O Anteprojeto tampouco seria objeto de debate público no país. Tudo levava a crer que a empreitada resultaria inútil.

Mas há evidências de que o Anteprojeto não dormitou indefeso nos arquivos. Dividido em partes, o documento seria apresentado como sugestão à mesa da constituinte pouco tempo depois. Afonso Arinos, eleito senador pelo Rio de Janeiro (PFL) e escolhido para a presidência da 64 comissão de sistematização da ANC, tinha dúvidas acerca da conveniência de apresentar formalmente o Anteprojeto da Comissão, receando que seu gesto fosse interpretado como uma limitação à soberania dos constituintes. Entretanto, no dia 24 de abril de 1987, o senador receberia um telefonema do deputado Ulysses Guimarães, presidente da Constituinte, o qual solicitava que apresentasse a proposta dos "Notáveis" à Mesa da Assembleia ${ }^{38}$.

O material circularia nos bastidores do Congresso Nacional das mais variadas maneiras. De maneira informal, partes significativas do seu texto eram copiadas por constituintes na elaboração de suas propostas, o que levou o depu-

\footnotetext{
${ }^{38}$ Segundo Cittadino (2000), tanto o Jornal de Brasília quanto o Jornal do Brasil, do mesmo dia, publicaram reportagens intituladas, respectivamente: "Congresso terá como base Anteprojeto de Notáveis" e "Arinos apresenta proposta", informando não apenas sobre o telefonema de Ulysses Guimarães como da decisão do Senador Arinos de distribuir os capítulos do Anteprojeto dos Notáveis às subcomissões da Constituinte.
} 
tado Manoel Moreira (PMDB-SP) a observar: "No lugar de plagiar, vamos examinar logo o original” (apud Cittadino, 2000). Ademais, vários dos membros da Comissão Arinos participariam direta e intensamente dos trabalhos da $\mathrm{ANC}^{39}$.

\section{Vox Populi: A Igreja e o "Plenário Pró-Participação Popular"}

As atividades da elite política e dos atores partidários nas preliminares à Constituinte encontravam seu duplo na outra vertente a atuar na transição democrática: as forças populares. E o seu principal polo de irradiação de trabalhos era a igreja católica.

Apoiadora do Golpe de 1964 e aliada do regime que logo após se instaurou, essa igreja passou por uma transmutação fundamental a partir de meados da década de 1970. Ironicamente, os setores do catolicismo progressista aproveitaram intensamente as comunidades eclesiais de base estrutura de alta capilarização social que os conservadores haviam criado e desenvolvido país afora - na sua militância pelos direito humanos e na luta pela reconstitucionalização, como relata Dalmo Dallari:

Quem criou no Brasil a Comunidade Eclesial de Base foi D. Eugênio Sales, que depois ficou com a imagem do bispo reacionário, ultraconservador. Mas ele era bispo do Rio Grande do Norte, e sabia da situação muito séria, de marginalização, de discriminação ali. E criou a Comunidade Eclesial de Base, que de certo modo era para se contrapor às Ligas Camponesas. A ideia básica então era essa: não são só os comunistas que estão preocupados

\footnotetext{
${ }^{39}$ José Afonso da Silva foi o principal assessor, durante todo o processo constituinte, do Senador Mário Covas (PMDB-SP), líder da maioria na ANC. Carlos Roberto de Siqueira Castro assessorou a liderança do PDT na ANC, além de ter destacada participação, conforme revelam suas atas, na comissão da soberania e dos direitos e garantias do homem e da mulher. Ambos os constitucionalistas integraram a comissão de redação, responsável pelo texto final da Constituição.
} 
com justiça social. Nós também estamos, a Igreja também se preocupa com justiça social. De modo que, ao lado das Ligas Camponesas, aparece a Comunidade Eclesial de Base. Elas depois se disseminaram pelo Brasil inteiro, e tiraram o nome Eclesial. Descobriram uma Comunidade de Base. É a organização básica da sociedade. E isso teve uma importância enorme. Tinha muito brasileiro que não era comunista e que não queria o comunismo, mas que aceitava e reconhecia a importância da organização comunitária, e isso teve muita importância no combate à ditadura. São elementos que vão se somando e que vão ter como resultado a Constituinte ${ }^{40}$.

Anos mais tarde, em depoimento, o líder social católico Francisco Whitaker lembraria que a inflexão política da igreja católica rumo à reconstitucionalização decorreu principalmente da experiência da qual tinham participado 66 ele e o bispo (e advogado) D. Cândido Padim, num projeto denominado "Jornadas internacionais por uma sociedade superando as dominações". Tratou-se de um encontro mundial lançado em 1975, em Paris, que era a evolução de um projeto no qual a CNBB tinha decidido, em assembleia no Brasil, fazer algo no exterior sobre os direitos humanos no país. No primeiro momento, ainda não se falava em ordem constitucional, mas em restauração da normalidade democrática, da liberdade e do direito. Essa experiência convocaria inúmeros juristas de persuasão católica a atender à ampla mobilização popular que se formava.

Na década de 1980, essas movimentações passariam a colocar explicitamente em pauta a atuação popular numa futura assembleia constituinte. Um dos mais importantes instrumentos de ação foi a criação do "Projeto educação popular constituinte", como recorda o mesmo jurista:

\footnotetext{
${ }^{40}$ Depoimento concedido à equipe do Cedec, concedido em São Paulo, em 2008.
} 
Nessa época, já se começa a falar o que é uma Constituinte, o que é uma Constituição. A proposta era de que o povo tivesse intensa participação na Constituinte, inclusive preparando propostas para serem apresentadas lá. Passei a viajar pelo Brasil inteiro, para dar conta dos incontáveis convites de sindicatos, de delegação de mulheres, de diversos movimentos sociais. Me tornei uma espécie de "caixeiro-viajante" da Constituinte ${ }^{41}$.

Em 1983, D. Mauro Morelli, bispo da Arquidiocese de Duque de Caxias (RJ), e o sociólogo Betinho se lançaram num debate no Brasil inteiro por uma nova Constituição. No Rio, formou-se uma ampla frente pró-Constituinte com a participação de sindicatos, da $\mathrm{OAB}$ e de diversos movimentos sociais e de católicos do mundo acadêmico, como o professor Cândido Mendes.

Em São Paulo, também houve movimentação por uma Constituinte com ampla participação social. Foi quando se criou o Plenário Pró-Participação Popular, seguindo o princípio das jornadas internacionais ocorridas na França, numa opção metodológica pela prática política horizontal, como novamente recorda Whitaker:

Era um movimento - porque não tinha dirigentes, sendo um espaço aberto a todos aqueles que achavam que era preciso haver participação popular na Constituinte. Isso se expressava no slogan que a gente criou aí: Constituinte sem povo não cria nada de novo ${ }^{42}$.

Desde logo, o Plenário Pró-Participação Popular adotava posição e realizava campanha pela Constituinte exclusiva. Com a derrota do Substitutivo Bierrenbach, o grupo pas-

\footnotetext{
${ }^{41}$ Depoimento de Dallari, concedido à equipe do Cedec em São Paulo, em 2008.

${ }^{42}$ Depoimento de Francisco Whitaker, concedido à equipe do Cedec.
} 
sou a trabalhar em propostas a serem levadas diretamente à ANC - quando então receberiam a designação de "emendas populares".

\section{Eleições de 1986 - o PMDB vai ao paraíso}

Com a institucionalidade do país renovada e liberada pela reforma política no início da Nova República, a sociedade afluiu com vigor na criação de novas agremiações políticas. Nas eleições municipais de 1985, concorreram 29 partidos aqueles 5 que já haviam disputado o pleito de 1982 e outras 24 novas agremiações. Principal legenda oposicionista e condottiere da transição, o PMDB colheu magros resultados. A principal derrota foi em São Paulo, onde Jânio Quadros bateu Fernando Henrique Cardoso e revigorou as forças conservadoras. Em 1986, os resultados seriam inteiramente diversos.

Ainda que tenham sido as eleições para Constituinte a 68 atrair a cobertura da imprensa, o interesse dos eleitores se dirigiu para a disputa dos comandos dos estados. Tratava-se da segunda eleição para governador desde 1965 e a primeira feita sob a égide da nova institucionalidade política. Esse fenômeno incidiria com força nessas eleições. Graças ao impacto do Plano Cruzado, o PMDB desfrutava de elevadíssima popularidade. A legislação da época não exigia filiação partidária um ano antes da eleição; por meio dessa brecha, vários políticos do PDS deixariam o partido para concorrer pela agremiação oposicionista. Em Alagoas, Fernando Collor saiu do PDS, se filiou ao PMDB e venceu as eleições para o estado. No Rio de Janeiro, Moreira Franco deixou o PDS e igualmente se elegeu governador pelo PMDB. Com exceção de Sergipe, a legenda venceria em todos os estados da federação.

O landslide peemedebista implicaria uma espécie de transbordamento do voto de governador para as bancadas no Congresso Nacional. Em geral, a formação da chapa 
para os cargos proporcionais se organizava em torno do Executivo estadual. Acresce que, no contexto institucional-eleitoral de 1986, em que não havia mais o voto vinculado, os partidos voltavam a poder coligar e não havia eleição casada para prefeito, como a de 1982. Isoladamente, o PMDB amealhou 260 das 487 cadeiras na Câmara dos Depu$\operatorname{tados}^{43}$. No Senado, obteria 38 das 49 vagas em disputa. Era a maior bancada partidária da futura Constituinte - ainda que sob inchaço dos nouveaux opposants de 1982 e de 1986, oriundos, no final da contas, da legenda de sustentação do autoritarismo. Conjugado aos números obtidos pelo PFL, a Aliança Democrática detinha sozinha a maioria absoluta na futura ANC. O parceiro na superação do regime de 1964 seria também o sócio na construção da democracia?

\section{Uma Assembleia, duas constituintes}

Foram 583 dias de atividades - o mais longo processo constituinte que se tem notícia. Operante nessa longa jornada, a ausência formal de anteprojeto estava a lhe balizar os trabalhos. Mas a implosão e o desmanche da Aliança Democrática foi sua causa eficiente, a acontecer logo após o início dos trabalhos da ANC. Exauria-se ali o pacto político que havia criado a Nova República - perempto seu intento originário e heterogêneo em demasia os parceiros. Ao cindir-se, a Aliança fazia de PMDB e PFL os dois principais polos políticos na ANC, em torno dos quais os aliados preferenciais ou circunstanciais orbitariam ${ }^{44}$. De modo a destacar esta que nos parece ter sido a clivagem essencial dos trabalhos da Constituinte, simplificaremos e estilizaremos

\footnotetext{
${ }^{43}$ Dos trinta partidos que participaram do pleito, treze deles conseguiram eleger pelo menos um representante para a Constituinte.

${ }^{44} \mathrm{Nem}$ todos os enfrentamentos ocorridos na ANC decorreram de alinhamentos sistemáticos entre os polos políticos formados a partir de PMDB e de PFL. Ao que parece, não há uma lógica única de explicação para as ações, decisões e votações ocorridas na Constituinte. No entanto, a dicotomia captura a generalidade dos contenciosos ali havidos.
} 
as duas forças políticas em confronto sob a denominação de Sistematização e de Centrão.

Desde suas prístinas atividades, essas duas forças travariam embates, confrontos, blefes, ameaças, impasses. Os "buracos negros" - matérias do Projeto de Constituição nas quais nenhum dos dois blocos tinha força e voto para aprovar ou rejeitar cabalmente, implicando a paralisação do processo constituinte - seriam sua mais perturbadora expressão. Mas igualmente ocorreriam composições, convergências e conciliações, quando os dois ex-sócios políticos se viram obrigados a transigir, negociar e firmar acordos sobre as questões em disputa - sob a pena capital de não conseguirem produzir constituição alguma. A fusão de emendas coletivas seria seu mecanismo preferencial de avença. O padrão decisório da ANC se constituiu, assim, num modelo conflitivo-consensual, pelo qual os confrontos passaram para o texto final da Constituição de 1988

70 sob a forma de compromissos agenciados pelas lideranças partidárias a representar os dois blocos dominantes numa espécie de "casamento na polícia" dos antigos parceiros aliancistas.

À dinâmica conflito-consenso dos dois blocos nos trabalhos da ANC se associava uma escansão temporal a vincar os vinte meses, demarcando duas amplas fases e padrões de atividades, nítidas a ponto de merecerem distintas nomeações. Vivia-se, de início, a fase da "Constituinte popular", resultante de um arcabouço de funcionamento altamente descentralizado, consagrado pelo regimento interno da ANC, ensejando e trazendo para o interior do Congresso a participação de vasto rol de atores extraparlamentares: movimentos sociais os mais diversos, frenética atividade de lobbies e acutilante pressão dos interesses organizados sobre os legisladores. Esse período recobre a fase do trabalho nas 24 subcomissões e oito comissões temáticas, cujo arremate se daria na "grande comissão" - a instância agregadora 
que regimentalmente elaboraria o Projeto de Constituição. Capitaneado, sobretudo, pelo senador Mário Covas, o bloco Sistematização comandou essa primeira fase, que transcorreu de fevereiro a fins de 1987.

$\mathrm{Na}$ virada do ano, a insatisfação latente e dispersa da massa de constituintes deixados à margem dos trabalhos da "grande comissão" deu corpo a um núcleo de parlamentares hostis ao primeiro Projeto de Constituição, que criou o Centrão. O novo bloco levaria o Congresso à fase da "Constituinte Partidária”. Aí, perderiam nitidez os alinhamentos ideológicos e as demandas corporativas da fase anterior, e os acordos demandariam laboriosas e exaustivas negociações entre os principais líderes de partidos. Da mesa diretora, a sobrepairante figura de Ulysses Guimarães arbitraria as contendas e induziria os parlamentares ao rito do voto. Esse período recobriu o ano de 1988, quando as votações nominais do $1^{\circ}$ e $2^{\circ}$ turnos se desenrolaram no plenário do Congresso Nacional.

A longa sombra da Presidência da República se projetaria sobre as duas fases da Constituinte. Desde a sua instalação até os derradeiros momentos da ANC, o governo Sarney atuaria de molde a condicionar, interferir e mesmo a pautar o processo constituinte. O Congresso Nacional reagiria de forma oscilante, ora cedendo às pressões do Executivo, ora confrontando-o e rejeitando sua agenda. Não é um enigma menor atinar para o que efetivamente pretendia Sarney. Para que ele queria os cinco anos de mandato? Por que a insistência na preservação do presidencialismo? A conquista dessas duas reivindicações, note-se, não aplacaria as críticas e pressões que ele seguiria movendo contra a ANC. Não é desconhecido que, em contextos de transição política, as forças da velha ordem tendam a convergir para o Executivo - sobretudo para o presidente da República em busca de garantias de que seus interesses serão preservados (O’Donnell et al., 1986) Assim havia ocorrido com 
Tancredo Neves nos acordos explícitos e implícitos que patrocinou. Que garantias buscavam então com Sarney, a ponto de levá-lo a um ativismo pontuado por mudanças de estratégias, e até mesmo de estrategistas, no cerceamento sistemático à ANG? ${ }^{45}$

Ao "enigma-Sarney" se acresce a charada fundamental acerca dos trabalhos constituintes: como uma assembleia de majoritária composição conservadora logrou produzir um documento final de natureza indubitavelmente progressista? Na literatura dedicada ao tema, autores avançaram a hipótese de que as regras de funcionamento da ANC instituídas pelo PMDB no regimento interno privilegiaram a decisão de membros da centro-esquerda em postos-chave do processo, que atuaram em aberta dissonância com as preferências da maioria que compunha o corpo coletivo (Gomes, 2002). As duas fases da ANC, porém, transcorreram sob bases institucio-

72 nais muito distintas, e mesmo as novas regras regimentais patrocinadas pelo Centrão não lhes conferiu capacidade de remover do texto constitucional as inovações progressistas. A explicação institucionalista não parece suficiente para solver o quebra-cabeça. Há também hipóteses que pretendem explicar a extensão, o grau de detalhamento e as inconsistências presentes na versão final da Constituição pela combinação de uma sistemática de trabalhos legislativos ultradescentralizados com a lógica do cálculo político dos deputados e senadores - na pele de constituintes, mantinham inabalados seus interesses eleitorais em sua atuação na ANC. O texto final - extenso, detalhista, em que atendimentos corporativos são visíveis a olho

\footnotetext{
${ }^{45}$ Sarney mobilizou de militares a governadores do PMDB. Entre seus estrategistas mais próximos, estavam Marco Maciel, Paulo Brossard e Saulo Ramos. Também consultava com frequência Jarbas Passarinho e os jornalistas Carlos Chagas e Carlos Castello Branco.
} 
nu - expressaria cabalmente o efeito dessas duas lógicas a operar nos trabalhos constituintes ${ }^{46}$.

Tais questões remanescem inconclusivas até hoje. Passemos então ao consabido, aos episódios estelares de cada fase da ANC e suas vicissitudes.

\section{Sistematização e a "Constituinte popular"}

Represada pelos anos de autoritarismo e reativada pelos eventos do final da década de 1970, uma vasta agenda de direitos se apresentou na fase inicial da ANC. Remobilizados após a derrota das diretas-já, os movimentos sociais fariam da Constituinte uma espécie de revanche da transição política pactuada, como avalia Genoíno Neto em depoimento:

Essa é uma particularidade da transição no Brasil: o movimento popular não foi cooptado pela transição pelo alto. O PT e a esquerda ficaram numa ala esquerda, sem ser domesticado, e o movimento social não foi cooptado. As comunidades populares e o movimento sindical vieram paralelamente a isso. E nós colocávamos eles todos para dentro. Entravam conosco no Plenário, usávamos as nossas prerrogativas de deputados federais no limite ${ }^{47}$.

Não seriam apenas as forças populares a comparecer e a se infiltrar maciçamente no plenário e nas galerias. Forças Armadas, membros do Judiciário, polícias,

\footnotetext{
${ }^{46}$ A "hipótese dos detalhamentos corporativistas" não enxerga o aspecto da implementação exitosa da nova Constituição, a faceta do alto grau de estabilidade que essa Constituição logrou alcançar nesses 25 anos que se seguiram à sua promulgação, graças, possivelmente, ao reconhecimento da parte das mais diversas forças políticas do país de terem seus interesses contemplados no texto constitucional.

${ }^{47}$ Depoimento de José Genoíno à equipe de Cedec, em julho de 2008.
} 
representantes de bancos, de entidades patronais, estatais, multinacionais, mineradoras etc. transitaram com desembaraço pelos corredores e dependências do Congresso Nacional. Nessa fase, estima-se que 9 milhões de pessoas tenham passado pelo Congresso e, ao todo, mais de 60 mil propostas de segmentos diversos da sociedade civil seriam apresentadas às subcomissões da ANC. O país desejado ali se delineava.

\section{"Todo poder à Constituinte"?}

Vencidas, mas não convencidas, na convocatória de uma Assembleia exclusiva em 1985, as forças progressistas lançariam uma arremetida por uma Constituinte soberana tão logo a ANC se instalasse. No cerne da contenda, estavam a natureza da transição política brasileira e suas implicações para a construção da nova ordem institucional.

Tanto na opinião pública como no plenário do

74 Congresso, as duas correntes travariam uma luta radical. Inconformados com o possível atrelamento da nova ordem constitucional ao poder constituído anterior, aqueles que consideravam a Constituinte plenamente soberana pressionavam para que os parlamentares assumissem desde logo o controle sobre a situação política do país, que confirmassem ou não o presidente da República no cargo e que estabelecessem um calendário da transição para o novo governo - além de adotar decisões que revogassem de pronto os institutos autoritários ainda vigentes. Já aqueles que insistiam no caráter incontornavelmente derivado da Constituinte defendiam a limitação do corpo constituinte à elaboração do novo documento constitucional, sem interferir na força institucional anterior à promulgação; alarmados pelos riscos do "todo poder à Constituinte", sustentavam que a integralidade de suas prerrogativas somente haveria de se manifestar com a vigência da futura Constituição. Para tais forças conservadoras, a inexistência 
de ruptura no processo político brasileiro desqualificava a convocação de uma Constituinte originária ${ }^{48}$.

O governo Sarney logo tomaria posição pela segunda opção, procurando preservar seus poderes e limitar o campo de ação dos constituintes. Na equipe presidencial, Saulo Ramos era o principal e mais agressivo propagandista da tese antisoberanista: "Só há Constituinte originária se há ato revolucionário que implique quebra, ruptura da ordem jurídica, sob pena de a Constituinte revelar-se derivada e, portanto, submetida à ordem jurídica em vigor"(Ramos, 1987, p. 21). Ele iria mais longe, e, em escrito publicado em pleno funcionamento da ANC, em setembro de 1987, sustentaria as limitações da Constituinte em onze amplos aspectos temáticos, mercê de sua natureza de emenda à Constituição Federal de 1967. O opúsculo, assim como seus constantes pronunciamentos na mídia atacando a ANC, possivelmente suscitaram aos constituintes a ideia e a propositura do que chamaram de "projeto de decisão". Tratava-se de um recurso jurídico para "sobrestar medidas que possam ameaçar os trabalhos e as decisões soberanas na Assembleia Nacional Constituinte”. Na prática, o Congresso Nacional passaria a deter o comando político do país. Mas o instituto não encontraria acolhida no seio da ANC; submetido a votação, a maioria congressual o derrotaria.

O governo persistia na pressão sobre a atuação dos constituintes. Em 19 de maio, nas rádios e na TV, Sarney fez um pronunciamento à nação, no qual manifestava divergências em relação aos trabalhos de elaboração constitucional e a seu conteúdo. Anunciava, em especial, que abria

\footnotetext{
${ }^{48} \mathrm{Na}$ obra de 1981, Faoro já havia rebatido de antemão o argumento de que somente uma revolução propiciaria os fundamentos de uma Constituinte soberana, ao escrever que "é duvidosa a tese de que só as revoluções vitoriosas podem convocar constituintes. Assembleias Constituintes podem ser o meio de enfrentar uma crise em perspectiva e lançar bases da transição, como sucedeu no Brasil, em que a Constituinte de 1823 foi convocada antes da Independência, pelo Decreto de 3 de junho de 1822" (Faoro, 1981 p. 95).
} 
mão de um ano de mandato constante na Carta Constitucional então vigente - seis anos - e definia unilateralmente a duração de seu mandato em cinco anos. O país conhecia um novo Dia do Fico.

\section{A definição do núcleo político}

Já no dia seguinte à sua instalação, a escolha da presidência da ANC entrava em pauta. Duas candidaturas almejavam o posto: Ulysses Guimarães (PMDB-SP) e Lysâneas Maciel (PDT-RJ), replicando, ainda uma vez, a disputa "moderados" e "autênticos" durante a transição, quando ambos eram emedebistas. A vitória de Ulysses se deu por larga margem. O segundo round da disputa no interior do PMDB ocorreu com a contenda Ulysses versus Fernando Lyra pela presidência da Câmara dos Deputados. Nova vitória de Ulysses, cumulando-o com uma tríplice presidência - do PMDB, da Câmara e da ANC.

Seguiu-se o processo de escolha das lideranças partidárias. A maioria das agremiações atribuiu a função de "líder na Constituinte" para um de seus parlamentares que já ocupavam a liderança na Câmara ou no Senado. O PMDB, no entanto, optaria pela escolha de uma liderança específica na ANC, o que motivou disputa acirrada entre o senador Mário Covas e o deputado ulyssista Luiz Henrique. A vitória de Covas tornou-se um fato político significativo para todo o processo, ao contestar o comando partidário e imprimir uma orientação de centro-esquerda à legenda. Ali começava o estranhamento PMDB-PFL. Ali se dava o início do fim da Aliança Democrática.

Covas infligiria nova derrota a Ulysses na escolha do relator-geral da ANC. Ambicionada por Fernando Henrique, Covas impõe Bernardo Cabral na função ${ }^{49}$. A Cardoso

\footnotetext{
${ }^{49}$ Que tinha sido seu vice-líder no MDB em 1969, quando ambos foram cassados pelo AI-5.
} 
tocaria a nevrálgica relatoria do regimento interno, definidor das regras de funcionamento da ANC e de suas instâncias decisórias.

Na composição da mesa diretora, a Constituinte conheceria mais um impasse político. Segundo partido em número de constituintes, o PFL impôs várias condições para participar da mesa da ANC; não conseguindo apoio, terminou fora da chapa unitária. No confronto, o PFL, por sua liderança, chegou a ameaçar fazer uma "Constituinte paralela", no que seria dissuadido por membros mais moderados, inclusive pelo então ministro da Educação, Marco Maciel $^{50}$. O episódio, no entanto, estremeceria as relações no interior da Aliança Democrática. O término formal desta se daria nesse episódio.

\section{A querela do regimento interno}

Entre fins de dezembro de 1986 e princípio de 1987, a assessoria da Câmara dos Deputados, por inspiração do presidente Ulysses Guimarães, formulou uma minuta de regimento interno da ANC calcada no modelo de 1946, em que se previa a formação de uma comissão constitucional para preparar o Anteprojeto (Andrade e Bonavides, 1991). A minuta, entretanto, não prosperaria. Na disputa interna no PMDB pela presidência da Câmara dos Deputados, Fernando Lyra advertia os parlamentares para o risco de criar-se uma grande comissão, cuja composição prevista era de 80 constituintes, 1 relator geral e vários auxiliares. Sua extensão e prerrogativas implicariam o risco de repartir o Congresso em constituintes de primeira e de segunda classe. Lyra alegava também que não haveria como ocupar o tempo dos parlamentares que ficassem ociosos aguardando a preparação do Anteprojeto, a dar-se no recinto privilegiado da "grande comissão".

\footnotetext{
${ }^{50}$ Que depois iria integrar a ANC, na condição de senador e ativa liderança do Centrão.
} 
$\mathrm{O}$ assunto entraria em pauta na primeira reunião ordinária da $\mathrm{ANC}$, o que desencadearia intenso debate sobre a natureza e o formato do processo constituinte. A decisão: não haveria nem comissão constitucional nem Anteprojeto prévio. Todos os constituintes participariam direta e igualmente do processo. Ainda a ser elaborado, incumbiria às normas do regimento interno a missão de instituir a estrutura, o calendário, os mecanismos e os procedimentos de elaboração do Projeto de Constituição. O formato adotado consistiria na criação de 24 subcomissões, que se agregariam, três a três, em oito comissões temáticas, por sua vez com matérias englobadas e consolidadas numa comissão de sistematização, responsável por montar o Anteprojeto. O deputado Nelson Jobim (PMDB-RS) evoca a concepção quase lúdica que orientou a montagem das instâncias de trabalho:

[...] tivemos de criar um imenso modelo, extraordinariamente complicado, de criação de 24 subcomissões. [...] Surgido o problema, pegamos os três volumes que reuniam as constituições ocidentais editadas pelo Senado e recortamos com tesoura os nomes de títulos e capítulos de todas aquelas constituições. E, durante uma noite inteira, colocando no chão, terminamos a distribuição daquilo tudo. E aí surgiu o seguinte: houve nomes de títulos e capítulos que se reproduziam em todas as constituições. Chamamos, então, de matéria absolutamente constitucional. Houve nomes de títulos e capítulos que se repetiam na maioria das constituições. Chamamos de matéria relativamente constitucional. E houve um número de títulos de capítulos que se repetiam na minoria das constituições, menos de 50\%. Chamamos de matéria relativamente não constitucional. [...] Neste modelo é que foram elaboradas as 24 subcomissões, que se centravam em grandes temas: eram as oito comissões temáticas, que eram os oito títulos da Constituição de hoje (Sampaio, 2004, pp. 11-2). 
Duas consequências adviriam do formato delineado naquele regimento. Em termos substantivos, as oito comissões temáticas na realidade predefiniam os capítulos da vindoura Constituição. Em termos operacionais, a divisão de trabalho em duas dúzias de fóruns decisórios implicava altos custos para uma posterior compatibilização e consistência das matérias apresentadas. Tal incentivo aos particularismos era justificado pelas oportunidades de participação dos atores extraparlamentares, na forma de sugestões iniciais de qualquer associação, assim como das câmaras municipais; audiências públicas obrigatórias, nas quais não só especialistas e autoridades poderiam ser convidados como, sobretudo, entidades associativas teriam o direito de apresentar-se e opinar; haveria a possibilidade de apresentação de emendas populares e a defesa de tais propostas ante a comissão de sistematização diretamente por um dos seus signatários ${ }^{51}$.

O regimento interno atribuía o direito de emendas a qualquer constituinte, e o número veio a ser expressivo: 20.790. Mas a grande novidade ficava por conta da chamada emenda popular ${ }^{2}$. Trinta mil eleitores poderiam subscrever uma proposta organizada sob a responsabilidade de pelo menos três entidades associativas e apresentá-la diretamente na ANC. No total, houve 122 emendas populares, portando nada menos que 12.277.423 assinaturas ${ }^{53}$. Desse montante, 83 emendas populares foram admitidas no processo constituinte.

\footnotetext{
${ }^{51}$ É notável que, ao lado de tão inusitado mecanismo de abertura social, o plenário da ANC tenha resistido à submissão do futuro texto, em algum momento de sua elaboração, ao plebiscito da nação. Para mediar essa questão, o regimento da ANC previu um prazo e um momento para a apreciação de propostas de referendo ou plebiscito, sem que nenhuma delas lograsse êxito.

${ }^{52}$ Houve um precedente remoto dessa modalidade de participação na Assembleia Constituinte de 1823, na figura das "sugestões de cidadãos".

${ }^{53}$ Cada eleitor podia subscrever até três propostas. A efetiva mobilização e a participação popular, portanto, foi da ordem de 4 milhões de cidadãos.
} 


\section{Covas e a estratégia da Sistematização ${ }^{54}$}

O passo seguinte foi organizar as comissões temáticas e suas subcomissões, além da poderosa comissão de sistematização. Na definição política dos cargos internos de comissões e subcomissões, o PMDB, partido majoritário da ANC, conseguiu assegurar a maioria das relatorias, distribuindo presidências e vice-presidências entre as demais agremiações. Para as forças progressistas, foi um momento decisivo: em troca da cessão do cargo da presidência de cada uma das comissões temáticas, Covas firmou acordo com José Lourenço, líder do PFL, para obter 7 das 8 relatorias em jogo. E escolheu a dedo, dentre parlamentares progressistas do PMDB, esses relatores, que seriam também membros natos da Sistematização. O circuito se fechava. Do recolhimento das matérias apresentadas à elaboração do Anteprojeto, o PMDB covista exercia seu predomínio.

Em 26 de junho de 1987, o relator-geral Bernardo

80 Cabral dava a público a primeira tentativa de organizar as partes votadas nas comissões temáticas. Era um anteprojeto de constituição com 501 artigos, distribuídos em dez títulos. Em 15 de julho, começava a tramitar o Projeto Zero - o primeiro texto oficial da futura Constituição. A Constituinte percorrera cinco meses e meio para chegar ao seu ponto de partida formal. Uma crise política se instalou, e o deputado José Richa (PMDB-PR) propôs suspender por um mês o funcionamento da ANC. Acabaria voto vencido.

No mês de outubro de 1987, tornou-se necessária mais uma prorrogação de prazo para a comissão de sistematização. Os trabalhos seriam consideravelmente embargados pelas divergências que se acentuavam e que estavam originando

\footnotetext{
${ }^{54}$ Originalmente, a mesa da comissão de sistematização era a seguinte: presidente: Afonso Arinos (PFL-RJ); 1 vice-presidente: Aluízio Campos (PMDB-PB); 2o vice-presidente: Brandão Monteiro: (PDT-RJ). Em vistas dos impasses, acrescentaram-se mais dois vice-presidentes, que teriam participação positiva para organizar e acelerar as deliberações: Jarbas Passarinho (PDS-PA) e Fernando Henrique Cardoso (PMDB-SP).
} 
um grupo que pretendia modificações regimentais. No plenário da Constituinte, ocorria uma revolta da maioria dos parlamentares, que ficavam sem uma participação direta, enquanto a comissão de sistematização deliberava e votava. Em 18 de novembro, a Sistematização conclui o projeto da nova carta política. As polêmicas desencadeadas pelo documento arrojariam a ANC em nova fase de funcionamento.

\section{Centrão e a "Constituinte partidária"}

Em fins de 1987, formou-se um bloco parlamentar que se autodesignava "Centro Democrático" (Centrão) ${ }^{55}$. O estopim de sua organização, entretanto, vinha de muito antes. Preliminarmente, nas divergências quanto ao quorum de deliberações ainda no momento de formação do regimento interno: para o PFL, o quorum deveria se dar por maioria absoluta de toda a ANC; para as lideranças do PMDB, por maioria simples dos presentes na votação. Decisivamente, quando a comissão de sistematização aprova a estabilidade no emprego - sem considerações de tempo de serviço ou outras exigências. Operacionalmente, com a insatisfação generalizada com o teor do documento produzido pela "grande comissão".

Essa fase marcou a ascensão das lideranças partidárias no papel preponderante e organizador das deliberações, barganhas e acordos para viabilizar as votações no plenário. Um "colégio de líderes", instância informal de consulta e decisão, se formou a partir dessas continuadas reuniões e passou a centralizar as atividades constituintes.

A reforma do Regimento pelo Centrão implicaria também uma apreciável concentração de poderes no presidente da ANC, Ulysses Guimarães -, seja por sua intervenção direta, seja

\footnotetext{
${ }^{55}$ Suas lideranças eram as seguintes: Roberto Cardoso Alves (PMDB-SP); Afif Domingos (PL-SP); José Lourenço (PFL-BA); Ricardo Fiúza (PFL-PE); Delfim Netto (PDS-SP); Arnaldo Faria de Sá (PTB-SP); José Maria Eymael (PDC-SP); Gastone Righi (PTB-SP); Roberto Jefferson (PTB-RJ); Paes Landim (PFL-PI); Expedito Machado (deputado, PMDB-CE); Sólon Borges dos Reis (PTB-SP).
} 
pela necessidade de que ele, a todo momento, interpretasse as normas de funcionamento e tomasse as decisões gerais. Sob as novas bases institucionais, Ulysses passaria a ser o elemento-pivô do processo de negociação das lideranças partidárias.

\section{A virada do Centrão}

Já no final dos trabalhos da comissão de sistematização, articulava-se uma maioria dos constituintes em torno da bandeira da modificação do regimento interno. Apoiando-se inicialmente num documento inspirado pelo Palácio do Planalto, intitulado "Democracia e desenvolvimento", o Centrão estreiou com uma demonstração de força, ao aprovar o Substitutivo Cardoso Alves para o regimento interno da Constituinte. O novo bloco político conseguira derrubar o item do regimento que conferia preferência às emendas provenientes da comissão de sistematização nas votações em plenário: agora, passavam a ter preferência aquelas 82 emendas assinadas por metade mais um dos constituintes. Com esse dispositivo, o Centrão conseguia retirar parte considerável do poder dessa comissão em matéria de decidir o andamento da pauta da Constituinte.

Controvérsias e negociações conduziram por fim à aprovação da resolução n. 3, publicada em 5 de janeiro de 1988. Desaparecia a comissão de sistematização, substituída pela figura individual do relator-geral. Para a redação final do Projeto, foi prevista a criação de uma comissão específica. Além das emendas individuais e coletivas, foram previstos os instrumentos de destaques para uma emenda e do requerimento de preferência. A votação de primeiro turno em plenário teve início com a Assembleia Constituinte já datando um ano de sua instalação.

\section{Confrontos e composições: a dinâmica política no Plenário}

Em 27 de janeiro de 1988, surgiu o primeiro impasse em Plenário, a repetir-se seguidamente: a emenda coletiva 
sobre o Preâmbulo e no Título I da Constituição não obteve os 280 votos para aprovação e teve de ser submetida a uma negociação informal. Doravante, essa forma de conduzir a votação tipificaria os acordos entre as duas forças majoritárias. A base era o texto do Centrão; para que fosse aceito, já se faziam preliminarmente alterações de consenso. Isso, no entanto, não impedia que as divergências restantes fossem a voto, na confrontação das partes. $O$ resultado prático era que o texto da Comissão de Sistematização era recuperado em sua maior parte.

Em julho de 1988, cinco meses após terem sido iniciadas, as votações em primeiro turno estavam concluídas. As votações de segundo turno iniciaram-se sob elevada tensão. Haviam surgido propostas para uma revisão geral, no mérito, do que já tinha sido aprovado, ou mesmo de recomeçar a tarefa constituinte. As divergências entre o Governo e os setores da Constituinte aprofundavam-se em pronunciamentos oficiais e por meio da imprensa. Em cadeia de rádio e TV, o presidente da República criticou frontalmente os conteúdos do Projeto B:

[...] há o receio de que alguns dos seus artigos

desencorajem a produção, afastem capitais, sejam adversos à iniciativa privada e terminem por induzir ao ócio e à improdutividade. [...] E que o povo, em vez de enriquecer, venha a empobrecer; e possa regredir, em vez de progredir. Em suma: os brasileiros receiam que a Constituição torne o País ingovernável (apud Delgado, 2006 p. 315).

Sarney é rebatido, no dia seguinte, com uma declaração incisiva de Ulysses Guimarães, também levada ao ar em cadeia nacional de rádio e televisão:

Não ouvimos o establishment, encarnado no Velho do Restelo, conclamando, na praia alvoaçada da partida, 
Vasco da Gama, Pedro Álvares Cabral e Camões para permanecerem em casa, saboreando bacalhau e o caldo verde, ao invés da aventura das Índias, do Brasil e dos Lusíadas e amaldiçoando "o primeiro que, no mundo, nas ondas velas quis em seco leão”. Esta Constituição terá cheiro de amanhã, não de mofo. [...] A governabilidade está no social. A fome, a miséria, a ignorância, a doença inassistida, é que são ingovernáveis. [...] Repito: esta será a Constituição cidadã. Porque recuperará como cidadãos milhões de brasileiros. [...] Esta Constituição, o povo brasileiro me autoriza a proclamá-la, não ficará como bela estátua inacabada, mutilada ou profanada. O povo nos mandou aqui para fazê-la, não para ter medo. Viva a Constituição de 1988. Viva a vida que ela vai defender e semear (apud Delgado, 2006).

A votação do texto em globo alcançou expressiva maio84 ria, confirmando o trabalho de primeiro turno. Nessa segunda rodada de deliberações pelo plenário, os trabalhos ganharam mais velocidade, o número de destaques postos a voto foi reduzido, as sessões alongaram-se pelo dia inteiro e em parte da noite, em "esforço concentrado". Dominava o conjunto da Assembleia a necessidade de concluir e promulgar a Constituição $^{56}$. Desde sua instalação, os trabalhos constituintes consumiram vinte meses. Antes da comissão de sistematização, tinha havido quatro anteprojetos e projetos de Constituição. Do trabalho do relator-geral entre as duas rodadas de plenário, emergira mais um projeto. No segundo turno, novo projeto. Por último, houve o Projeto de Constituição feito pela comissão de redação final. Ao todo, seriam nove anteprojetos ou projetos, gestados na longa jornada constituinte.

\footnotetext{
${ }^{56}$ Com a saída de Mário Covas para a fundação do PSDB, a função de líder do PMDB fora atribuída ao deputado Nelson Jobim (RS). A ele caberia papel essencial nos momentos de divergência e negociação ao longo do segundo turno de votação.
} 


\section{"Chegamos!"}

O final das deliberações ocorreu na madrugada de 2 de setembro, numa Assembleia exaurida pela longa jornada de trabalhos. A data de promulgação estava definida desde o final do segundo turno, e a cerimônia aconteceu no dia 5 de outubro, às 15 h30, no plenário do Congresso Nacional. Pelos constituintes, falou o seu decano, o senador Afonso Arinos. Representando as delegações estrangeiras, Vitor Crespo, presidente da Assembleia Legislativa de Portugal, saudou da tribuna um Brasil democrático e reconstitucionalizado. Sarney não discursou; a fala do presidente não estava prevista. Ao lado de Ulysses Guimarães, aguardava o momento que devia jurar a Constituição brasileira. Com as mãos trêmulas, estendeu o braço para o pronunciamento. O papel que segurava, contendo umas poucas palavras protocolares, tremia também.

A fala final é de Ulysses Guimarães. Sereno mas vibrante, enfatizou a ampla e inovadora carta de direitos do documento agora promulgado. A Constituição cidadã recebera seu nome de batismo.

\section{Antônio Sérgio Rocha}

é docente de ciência política da Unifesp, membro associado e pesquisador do Cedec.

\section{Referências bibliográficas}

ANDRADE, P; BONAVIDES, P. 1991. História constitucional do Brasil. São Paulo: Paz e Terra.

BRANCO, C. C. 1982. "Liberar sem transferir poder”. Isto É, n.265, 20 jan, pp.68-70.

1984. "Tancredo-já e os cinco candidatos". Disponível em w http:// www.carloscastellobranco.com.br/sec_coluna_view.php?id=2263. Acesso em 04/03/2012

CARVALHO, J. M. 2010. A cidadania no Brasil: o longo caminho. Rio de Janeiro: José Olympio.

CARDOSO, F. H. 2006. A arte da política: a história que vivi. Rio de Janeiro: Civilização Brasileira. 
2010. Relembrando o que escrevi. Rio de Janeiro: Civilização Brasileira.

CITTADINO, G. 2000. Pluralismo, direito e justiça distributiva. Rio de Janeiro: Lumen Juris.

DELGADO, T. 2006. A história de um rebelde. Brasília: Fundação Ulysses Guimarães.

DIARIO do CN. 1984. "Reportagem". 16 maio, p.971. "Reportagem”. 27 de abr., p.2531.

ECHEVERRIA, R. 2011. Sarney: a biografia. São Paulo: Leya.

FAORO, R. 1981. Assembleia nacional constituinte: a legitimidade recuperada. São Paulo: Brasiliense.

FERREIRA FILHO, M. G. 1972. A democracia possivel. São Paulo: Saraiva.

FRANCO, A. A. M. 1982. "A constituinte instituída". Revista de Ciência Política, v.1, n.1, pp.3-17.

GASPARI, E. 2003. A ditadura derrotada. São Paulo: Cia. das Letras.

GOMES, S. N. 2002. A assembleia nacional constituinte e o regimento interno. São Paulo, 83p. Dissertação de mestrado. Faculdade de Filosofia Letras e Ciências Humanas da Universidade de São Paulo.

HAGOPIAN, F. 1996. Traditional politics and regime change in Brazil. Cambridge: CUP.

KINZO, M. D. G. 1988. Oposição e autoritarismo: gênese e trajetória do MDB, 1966/1979. São Paulo: Vértice.

LAMOUNIER, B. 1986. "Authoritarian Brazil revisado: o impacto das eleições na abertura política brasileira, 1974-1982”. Dados, v. 29, n.3, pp. 283-317.

LEÃO, E. 2004. Do MDB ao PMDB. Brasília: Fundação Ulysses Guimarães.

LINZ, J. J. 1973. "The future of an authoritarian situation or the institutionalization of an authoritarian regime: the case of Brazil". In: STEPAN, A. (org.). Authoritarian Brazil: origins, policies and future. New Haven: Yale University Press, pp. 233-54.

MACHADO, M. B.; TORRES JÚNIOR, I. V. G. (orgs.). 1997. Reforma constitucional. Rio de Janeiro: Casa de Rui Barbosa.

MOREIRA ALVES, M. H. 1984. Estado e oposição no Brasil (1964-1984). Petrópolis: Vozes.

NORONHA, E. 2010. "Mudança intitucional e a constituinte de 1998: temas e preferências de empresários e sindicalistas”. Trabalho apresentado no seminário do Cedec. São Paulo.

O’DONNELL, G. 1987. “A transição é um imenso pastiche”. Senhor, n.335, pp.5-13.

1990. Análise do autoritarismo burocrático. São Paulo: Paz e Terra. 
.et al. 1986. (orgs.) Transitions from authoritarian rule: comparative perspectives. Baltimore: John Hopkins University Press.

FERREIRA, O. S. 1986. Uma Constituição para a mudança. São Paulo: Duas Cidades.

PRZEWORSKI, A. 1986. "Some problems in the study of transitions". In: O'DONNELL, G. et al. (orgs.) Transitions from authoritarian rule: comparative perspectives. Baltimore: John Hopkins University Press, pp.47-62.

RAMOS, J. S. 1987. Assembleia constituinte: natureza, extensão e limitação de seus poderes. São Paulo: Alhamabra.

SAMPAIO, J. A. L. 2004. Quinze anos de constituição. Belo Horizonte: Del Rey.

SANTOS, W. G. 1978. Poder e política: crônica do autoritarismo brasileiro. Rio de Janeiro: Forense-Universitária.

1979. Cidadania e justiça: a política social na ordem brasileira. Rio de Janeiro: Campus.

SOARES, G. A. D. 1984. Colégio eleitoral, convenções partidárias e eleições diretas. Rio de Janeiro: Vozes.

SCHUBSKY, C. 2007. Estado de direito já: os 30 anos da carta dos brasileiros. São Paulo: Lettera.

VELASCO E CRUZ, S. 1995. Empresariado e estado na transição brasileira: um estudo sobre a economia política do autoritarismo. Campinas: Ed. da Unicamp.

VEJA, 1973. "O regime brasileiro: entrevista com Juan. J. Linz", n.274, 5 dez., pp.3-12.

1986. "Eu sou um elitista: entrevista com Afonso Arinos de Melo Franco”, n.956, 4 jun., pp.5-9. 